Article

\title{
2-Aminobenzothiazole-Containing Copper(II) Complex as Catalyst in Click Chemistry: An Experimental and Theoretical Study
}

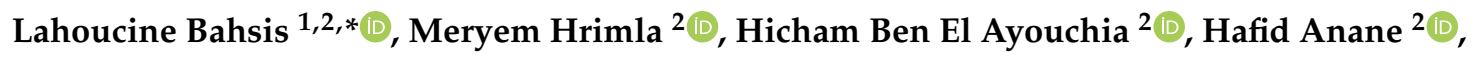 \\ Miguel Julve $^{3}$ and Salah-Eddine Stiriba ${ }^{2,3, *}$ \\ 1 Département de Chimie, Faculté des Sciences d'El Jadida, Université Chouaïb Doukkali, B.P.:20, \\ El Jadida 24000, Morocco \\ 2 Laboratoire de Chimie Analytique et Moléculaire/LCAM, Faculté Polydisciplinaire de \\ Safi, Université Cadi Ayyad, Safi 46030, Morocco; meryemhrimla.uca@gmail.com (M.H.); \\ belayou@gmail.com (H.B.); ananehafid@gmail.com (H.A.) \\ 3 Instituto de Ciencia Molecular/ICMol, Universidad de Valencia, C/Catedrático José Beltrán 2, Paterna, \\ 46980 Valencia, Spain; miguel.julve@uv.es \\ * Correspondence: bahsis.lahoucine@gmail.com (L.B.); stiriba@uv.es (S.-E.S.)
}

Received: 21 June 2020; Accepted: 7 July 2020; Published: 11 July 2020

\begin{abstract}
The reaction of copper(II) acetate with the 2-aminobenzothiazole (abt) heterocycle affords the new copper(II) complex of formula $\left[\mathrm{Cu}(\mathrm{abt})_{2}\left(\mathrm{OOCCH}_{3}\right)_{2}\right](\mathbf{1})$ in a straightforward manner. Compound 1 served as a precatalyst for azide/alkyne cycloaddition reactions (CuAAC) in water, leading to 1,4-disubstituted-1,2,3-triazole derivatives in a regioselective manner and with excellent yields at room temperature. The main advantages of the coordination of such a heterocyclic ligand in $\mathbf{1}$ are its strong $\sigma$-donating ability $(\mathrm{N}-\mathrm{Cu})$, nontoxicity and biological properties. In addition, the click chemistry reaction conditions using 1 allow the formation of a great variety of 1,2,3-triazole-based heterocyclic compounds that make this protocol potentially relevant from biological and sustainable viewpoints. A molecular electron density theory (MEDT) study was performed by using density functional theory (DFT) calculations at the B3LYP/6-31G(d,p) (LANL2DZ for $\mathrm{Cu}$ ) level to understand the observed regioselectivity in the CuAAC reaction. The intramolecular nature of this reaction accounts for the regioselective formation of the 1,4-regioisomeric triazole derivatives. The ionic nature of the starting copper-acetylide precludes any type of covalent interaction throughout the reaction, as supported by the electron localization function (ELF) topological analysis, reaffirming the zwitterionic-type (zw-type) mechanism of the copper(I)/aminobenzothiazole-catalysed azide-alkyne cycloaddition reactions.
\end{abstract}

Keywords: 2-aminobenzothiazole; click chemistry; CuAAC; MEDT; regioselectivity; ELF

\section{Introduction}

Triazole-containing heterocycles have found many applications in several disciplines, such as medicine, biology and materials science [1]. In general, these compounds are prepared through azide-alkyne cycloaddition (AAC) reactions [2,3]. Indeed, the non-catalyzed [3 + 2] cycloaddition (32CA) reaction, also known as "Huisgen's 1,3-dipolar cycloaddition", between azides and alkynes is characterized by low rates and small yields at room temperature, due to the high kinetic barrier of the reaction [4,5], as well as the formation of two isomers, that is, 1,4- and 1,5-disubstituted 1,2,3-triazoles. Later, the discovery by the groups of Meldal [6] and Sharpless [7] that copper(I) is capable of accelerating the 32CA reaction of azides and alkynes with high regioselectivity, to afford the 1,4-disubstituted 1,2,3-triazole isomer under mild conditions, led to a breakthrough of such 
a cycloaddition process. Since then, the copper-catalyzed azide-alkyne cycloaddition (CuAAC) reaction has become the most representative click reaction in the panorama of click chemistry due to its mild conditions and vast applications, in particular in life sciences [8-11]. However, the thermodynamic instability of copper(I), as well as its easy oxidation to copper(II), have led to the search for suitable stabilizing ligands for $\mathrm{Cu}(\mathrm{I})$ ion. Consequently, the formation of the active Lewis-acid copper(I) species is becoming crucial in developing $\mathrm{CuAAC}$ reactions in terms of stability and activity [12]. A variety of homogeneous catalytic systems were reported for the click of 1,4-disubstituted 1,2,3-triazoles [13-17]. In this regard, several polydentate ligands containing nitrogen atoms have been used to thermodynamically stabilize copper ions against destabilizing reactants found in the reaction medium. Some of these interesting ligands include the tris-(benzyltriazolylmethyl)amine (TBTA) [18], dipicolinate [19], tris(triazolyl)methanol (TBTM) [20], 2-pyrrolecarbaldiminato [21] and crowded tetradentate tris(2-dioctadecylaminoethyl)amine [22].

Inspired by Nature's strategy, the use of ligands with biological activities can broaden the CuAAC applications. Many heterocyclic nuclei, such as benzothiazole, have been recently reviewed as antimicrobial agents [23,24] and 2-aminobenzothiazole derivatives were reported with a variety of biological applications $[25,26]$. The 2-aminobezothiazole ligand (abt) contains sulfur and nitrogen in a ring, an exocyclic nitrogen and $\pi$-electrons, giving the ligand a high coordination ability. Its coordination to the metal center via the nitrogen atom of the ring occurs in most of the reported crystal structures [27, 28]. It is worth noting that the type of complexes have been widely studied as they exhibit interesting biological and photophysical properties [29-31].

Having in mind the above facts, we present here the synthesis of a $\mathrm{Cu}(\mathrm{II})$-abt complex in ethanol/water and the study of its catalytic potential for the click of 1,4-disubstituted-1,2,3-triazole compounds via azide-alkyne cycloaddition reactions in water at room temperature. A theoretical study by the MEDT method and ELF topological analysis is also carried out to explain the mechanism and intermediates species that participate in this chemical process. It deserves to be noted that the regioselective click of 1,2,3-triazoles is performed in absence of any reducing agent or additive bases, while the catalyst is found to be highly active at lower loadings.

\section{Results and Discussion}

The copper(II)-abt complex of formula $\left[\mathrm{Cu}(\mathrm{abt})_{2}\left(\mathrm{OOCCH}_{3}\right)_{2}\right](\mathbf{1})$ was simply prepared by the addition of an aqueous solution of copper(II) acetate to a methanolic solution of abt at room temperature (Scheme 1). Green crystals of $\mathbf{1}$ were grown from the resulting solution.<smiles>Nc1nc2ccccc2s1</smiles>

2-aminobenzothiazole (abt)

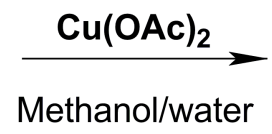

Methanol/water

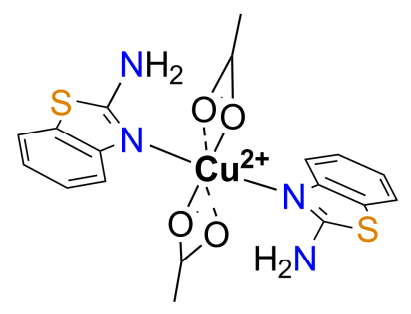

Complex 1

Scheme 1. Schematic illustration of the synthesis of $\mathbf{1 .}$

The optimized structure of $\mathbf{1}$ with the atom numbering of the non-carbon atoms is shown in Figure 1. Bond distances and angles of the complex $\mathbf{1}$ are summarized in Table 1. The copper(II) ion in $\mathbf{1}$ is six-coordinate with two trans-positioned nitrogen atoms from to abt molecules and four oxygen atoms of two chelating acetate ligands building an elongated octahedral $\mathrm{CuN}_{2} \mathrm{O}_{4}$ environment. Each acetate ligand in $\mathbf{1}$ adopts an asymmetrical didentate coordination, with one short (1.981 and $1.980 \AA$ for Cu1-O1 and Cu1-O4, respectively) and one long (2.554 $\AA$ for Cu1-O2 and Cu1-O3) copper-oxygen bond lengths. The $\mathrm{Cu}-\mathrm{N}_{\mathrm{abt}}$ bond distances [2.130 $\AA$ for $\mathrm{Cu}-\mathrm{N} 5$ and $\mathrm{Cu}-\mathrm{N} 6$, respectively] are somewhat 
shorter than the longest copper to oxygen bonds. The value of the N5-Cu-N6 bond angle $\left(179.9^{\circ}\right)$ is very close to linearity. These findings are in agreement with the crystallographic data of this compound, whose single-crystal X-ray structure was reported by Dojer et al. in 2019 [28].

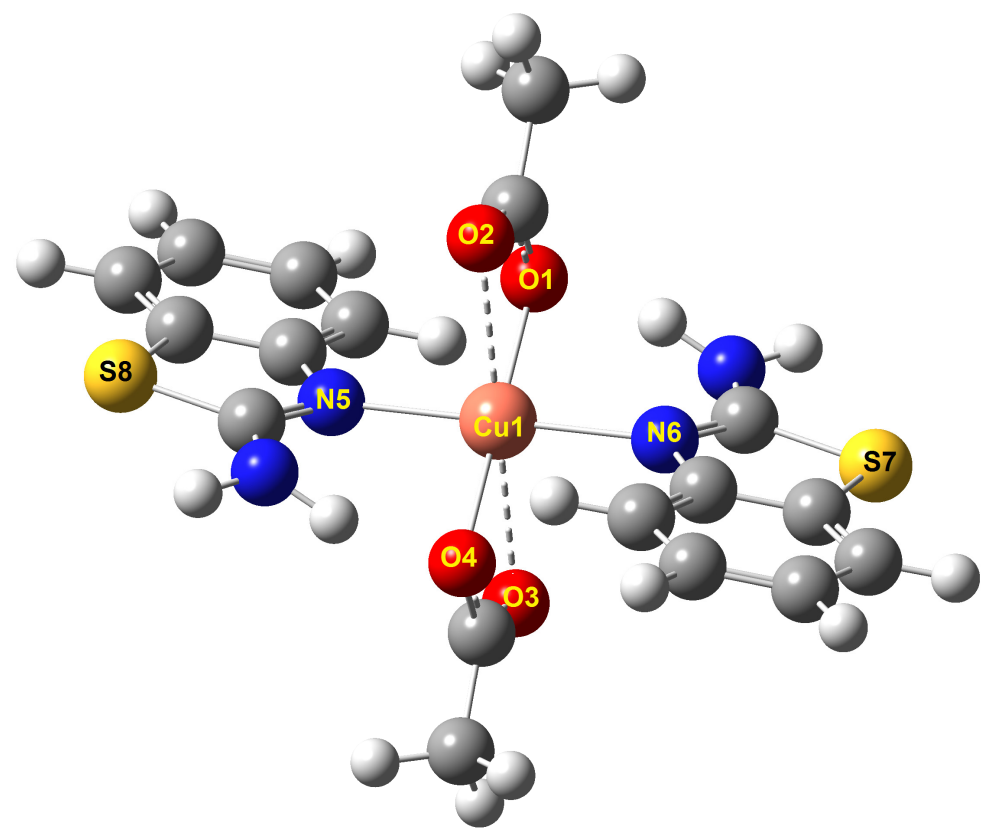

Figure 1. Optimized structures of 1 at the B3LYP/6-31G(d,p) (LANL2DZ for Cu) level.

Table 1. Some calculated and experimental structural parameters of $\mathbf{1}$.

\begin{tabular}{ccc}
\hline & Calculated & Experimental $^{\mathbf{a}}$ \\
\hline Bond Lengths (A) & & \\
\hline Cu1-O1 & 1.981 & 1.961 \\
Cu1-O2 & 2.554 & 2.548 \\
Cu1-O4 & 1.980 & 1.961 \\
Cu1-O3 & 2.554 & 2.548 \\
Cu1-N5 & 2.130 & 2.018 \\
Cu1-N6 & 2.130 & 2.018 \\
\hline Bond Angles ( $\left.{ }^{\circ}\right)$ & & \\
\hline O4-Cu1-N5 & 89.668 & 88.715 \\
O3-Cu1-N5 & 92.640 & 91.256 \\
O4-Cu1-N6 & 90.332 & 91.285 \\
O3-Cu1-N6 & 87.359 & 88.743 \\
O1-Cu1-N5 & 90.332 & 91.285 \\
O2-Cu1-N5 & 87.359 & 88.744 \\
O1-Cu1-N6 & 89.668 & 88.714 \\
O2-Cu1-N6 & 92.640 & 91.256 \\
N5-Cu1-N6 & 179.999 & 180.000 \\
\hline
\end{tabular}

${ }^{a}$ Values from ref [28].

\subsection{Catalytic Studies}

The as-prepared copper(II) complex was then tested in 32CA reactions between a variety of azides and terminal alkyne derivatives. The reaction between benzyl azide (1a) and phenylacetylene (2a) in the water at room temperature was chosen as the model reaction and it was performed under a variety of conditions (see Scheme 2 and Table 2). The controlled experiments showed that the 32CA reaction does not take place in the absence of the catalyst (entry 1). It was observed that the use of copper(II) 
acetate only in water as a reaction medium led to poor yields of the corresponding 1,2,3-triazole ca. $40 \%$ after stirring for $24 \mathrm{~h}$ at room temperature (entry 2). Interestingly, the corresponding 1,4-triazole was formed in high yields (98\%) within $12 \mathrm{~h}$ by using $5 \mathrm{~mol} \%$ of $\mathbf{1}$ and water as solvent (entry 5) compared with copper(II) sulphate in the presence of 2-abt as a ligand (entry 4). The catalyst loading for 1 could be further reduced to $2 \mathrm{~mol} \%$, affording an excellent yield of the corresponding 1,4-disubstituted 1,2,3-triazole (92\%) in water within $4 \mathrm{~h}$ at room temperature (Table 2, entry 7$)$. Further, several solvents were investigated for the model reaction (Table 2, entries 9-14). Hexane, ethanol, acetonitrile, acetone and toluene as solvents gave poor to moderate reaction yields (40-67\%, respectively). The ethanol/water solvent mixture also gave a moderate yield ca. $62 \%$ with $2 \mathrm{~mol} \%$ of the catalyst. As can be seen in Table 2, the maximum yield of the triazole product was obtained with $2 \mathrm{~mol} \%$ of the catalyst in water medium at room temperature.

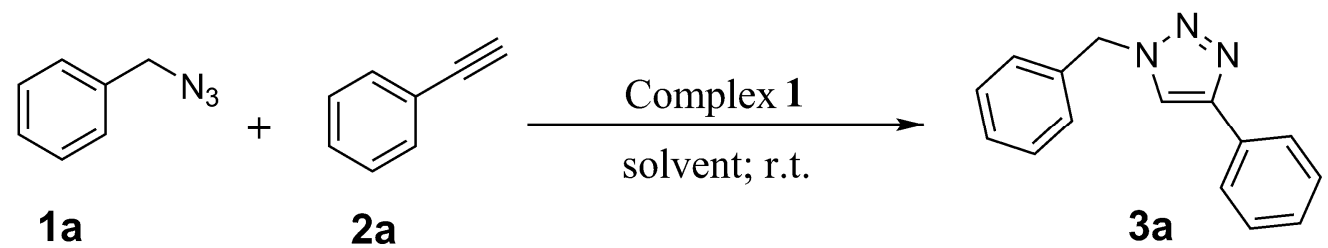

Scheme 2. Azide-alkyne cycloaddition in the presence of complex $\mathbf{1 .}$

Table 2. Optimization of reaction conditions for complex 1-mediated benzyl azide-phenylacetylene cycloaddition ${ }^{\text {a }}$.

\begin{tabular}{cccccc}
\hline Entry & Catalyst & Catalyst Loading $\mathbf{( m o l} \mathbf{\%})$ & Solvent & Time (h) & Yield (\%) \\
\hline 1 & abt & - & Water & 24 & Traces \\
2 & ${\mathrm{Cu}(\mathrm{OAc})_{2}}$ & 5 & Water & 24 & 40 \\
3 & $\mathrm{CuSO}_{4}$ & 5 & Water & 24 & 30 \\
4 & $\mathrm{CuSO}_{4}$ & 5 & Water & 12 & $85^{\mathrm{c}}$ \\
5 & $\mathbf{1}$ & 5 & Water & 12 & 98 \\
6 & $\mathbf{1}$ & 3 & Water & 4 & 96 \\
7 & $\mathbf{1}$ & 2 & Water & 4 & 92 \\
8 & $\mathbf{1}$ & 1 & Water & 4 & 74 \\
9 & $\mathbf{1}$ & 2 & Hexane & 4 & 40 \\
10 & $\mathbf{1}$ & 2 & Toluene & 4 & 51 \\
11 & $\mathbf{1}$ & 2 & Ethanol & 4 & 67 \\
12 & $\mathbf{1}$ & 2 & Acetonitrile & 4 & 64 \\
13 & $\mathbf{1}$ & 2 & Acetone & 4 & 56 \\
14 & $\mathbf{1}$ & 2 & Ethanol/water & 4 & 62 \\
\hline
\end{tabular}

a Reaction conditions: benzyl azide $(0.6 \mathrm{mmol})$, phenylacetylene $(0.5 \mathrm{mmol})$, solvent $(3 \mathrm{~mL})$ and catalyst. ${ }^{\mathrm{b}}$ Isolated yields. ${ }^{\mathrm{C}}$ Using 2 -abt as ligand.

Based on the above-optimized reaction conditions, the scope of our method was explored by using different para-substituted phenyl acetylenes as well as different benzyl and alkyl azides. The 32CA reactions progressed effectively to afford the corresponding triazole derivatives in a short time for all cases and the corresponding 1,2,3-triazoles were isolated in good to excellent yields (see Table 3). Interestingly, the clicking reaction between alkyne-containing polycyclic and benzyl or alkyl azides was conducted and the corresponding 1,2,3-triazoles were obtained in excellent yields by precipitation in water and without need for any further purification by conventional methods (see Table 3 , entries 11 and 12). The products were fully characterized by ${ }^{1} \mathrm{H}$ and ${ }^{13} \mathrm{C}$ NMR spectroscopy and mass spectrometry (see Supplementary Materials for details). 
Table 3. Click of 1,2,3-triazoles in the presence of complex $\mathbf{1}^{\mathrm{a}}$.

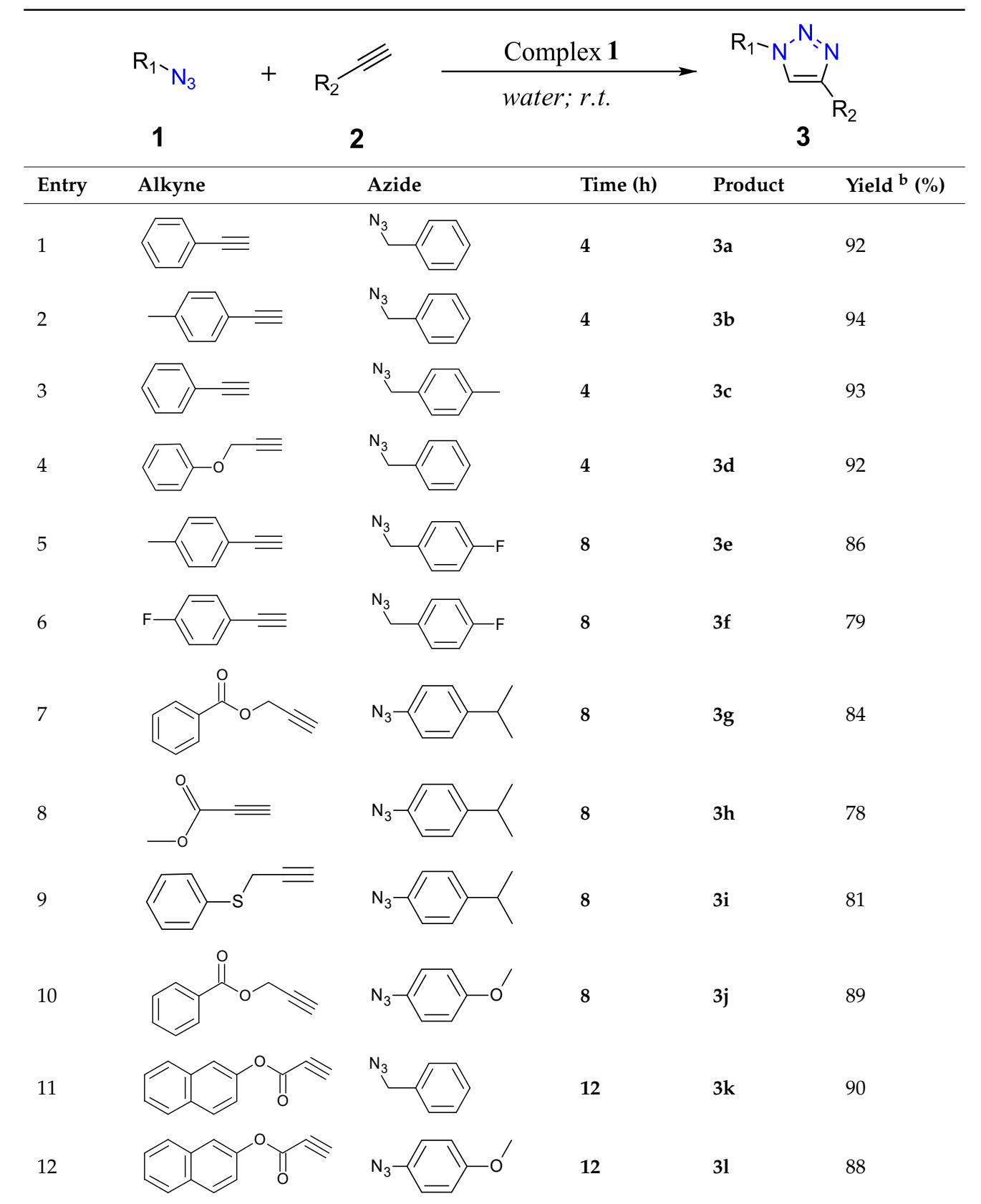

a Reaction conditions: azides $(0.6 \mathrm{mmol})$, alkynes $(0.5 \mathrm{mmol})$, water $(3 \mathrm{~mL}), 2 \mathrm{~mol} \%$ of catalyst, and room temperature.

${ }^{\mathrm{b}}$ Isolated yields.

\subsection{Comparison of Complex $\mathbf{1}$ with other Catalysts}

In order to prove the efficiency of the complex 1-mediated azide-alkyne cycloaddition reaction, a comparison of this catalyst with other copper(II) complexes for the reaction of phenylacetylene (1a) and benzyl azide (2a) to afford 1,4-disubstituted 1,2,3-triazoles was done (see Scheme 2 and Table 4). It was observed that the presence of a reducing agent, high temperatures and inert atmosphere are requisites to operate some catalytic systems. Importantly, complex 1 occurs in an effective manner for the synthesis of 1,2,3-triazole, working in air and at room temperature in water, followed by an easy work-up protocol for the final separation of the product. 
Table 4. Comparison of the catalytic performance of 1 with other literature reports in $\mathrm{CuAAC}$ reactions ${ }^{\mathrm{a}}$.

\begin{tabular}{|c|c|c|c|c|c|c|c|}
\hline Entry & $\begin{array}{c}\begin{array}{c}\mathrm{Cu} \\
\text { Loading } \\
(\mathrm{mol} \%)\end{array} \\
\end{array}$ & Additives & Solvent & $\mathrm{T}\left({ }^{\circ} \mathrm{C}\right)$ & Time (h) & Yield (\%) & Ref. \\
\hline Complex 1 & 2 & - & $\mathrm{H}_{2} \mathrm{O}$ & r.t. & 4 & 92 & This work \\
\hline $\mathrm{Cu}\left(\mathrm{NO}_{3}\right)_{2} \cdot 3 \mathrm{H}_{2} \mathrm{O}$ & 20 & - & $\mathrm{H}_{2} \mathrm{O}$ & r.t. & 20 & 13 & [32] \\
\hline $\mathrm{Cu}(\mathrm{II})$-tren & 0.2 & - & n-Octane & r.t. & 24 & 84 & [33] \\
\hline $\mathrm{Cu}(\mathrm{II})-\mathrm{MBHTM}$ & 1 & Sodium-ascorbate & $\mathrm{DMSO} / \mathrm{H}_{2} \mathrm{O}$ & r.t. & 4 & 94 & [34] \\
\hline $\mathrm{Cu}(\mathrm{II})-\mathrm{BPPA}$ & 0.2 & Sodium-ascorbate & $\mathrm{MeOH} / \mathrm{N}_{2}$ & r.t. & 16 & 99 & [35] \\
\hline$\left[\mathrm{Cu}(\mathrm{II})(\mathrm{Phox})_{2}\right]$ & 1.4 & - & $\mathrm{H}_{2} \mathrm{O}$ & 70 & 12 & 75 & [36] \\
\hline$\left[\left(\mathrm{C}_{2} \mathrm{H}_{5}\right)_{4} \mathrm{~N}\right]_{4}\left[\mathrm{~V}_{8} \mathrm{Cu}_{2} \mathrm{O}_{24}\right]$ & 0.34 & - & $\mathrm{H}_{2} \mathrm{O}$ & 70 & 4 & 88 & [37] \\
\hline
\end{tabular}

\subsection{Mechanistic Studies}

Based on the reported mechanism [38-44], the reaction mechanism for the synthesis of 1,4-disubstituted 1,2,3-triazoles in the presence of $\mathbf{1}$ is shown in Scheme 3. Firstly, the catalytic copper(I) species arises through the reduction of the copper(II) complex by the terminal alkyne via the oxidative alkyne homocoupling process [45]. Then, the in-situ coordination of the terminal alkyne to the copper(I) species leads to the dinuclear acetylide-copper intermediate. The reaction of this dinuclear complex and organic azide conducts to a six-membered ring, forming the triazolide ring intermediate. Finally, this intermediate easily provides the 1,4-disubstituted 1,2,3-triazole under slightly acidic conditions and regenerates the catalyst (Scheme 3).

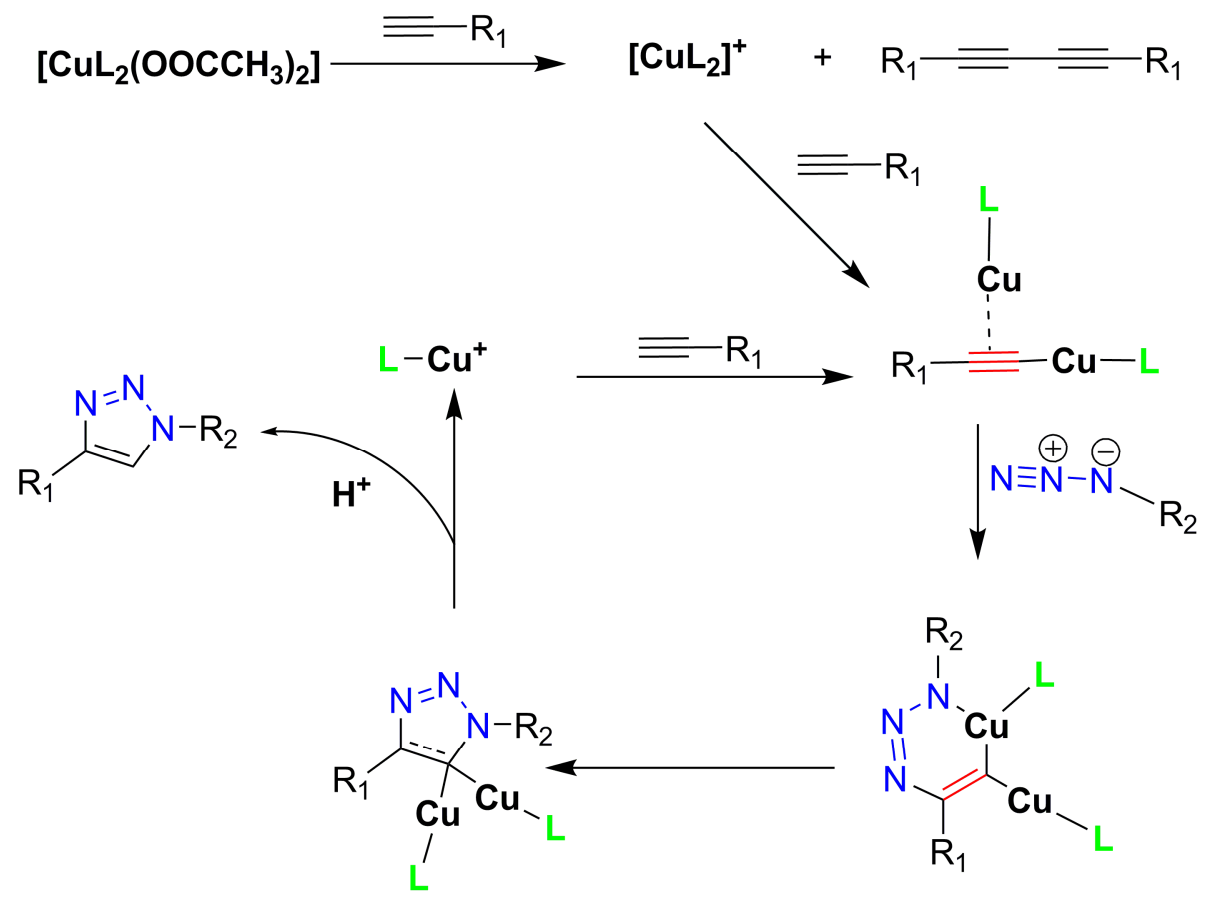

Scheme 3. Generally accepted mechanism of CuAAC catalyzed by complex $\mathbf{1}(\mathrm{L}=\mathrm{abt})$.

\subsubsection{MEDT Study}

Recently, the molecular electron density theory [46] (MEDT) was proved to be a powerful tool for the theoretical understanding of 32CA reactions allowing the explanation of the reactivity of the simplest three-atom-components (TACs) towards ethylene, based on their respective electronic structure [47]. Accordingly, the $\mathrm{CuAAC}$ reaction catalyzed by the $\mathrm{Cu}(\mathrm{I})$-abt complex was investigated through the MEDT study (Scheme 4). The terminal alkyne is firstly metallated with copper(I) via an easy deprotonation of the alkyne, yielding a binuclear copper(I)-acetylide species (see Scheme 4). 
After coordination of the azide to the copper(I)-acetylide, the cycloaddition subsequently affords the corresponding 1,2,3-triazole compounds. Herein, the reaction path associated to the CuAAC reaction of propyne (4) with methyl azide (5) yielding 1,4-dimethyl-1,2,3-triazole (6) is investigated within MEDT through DFT methods at level B3LYP/6-31G(d,p) (LANL2DZ for Cu) (see Scheme 4).

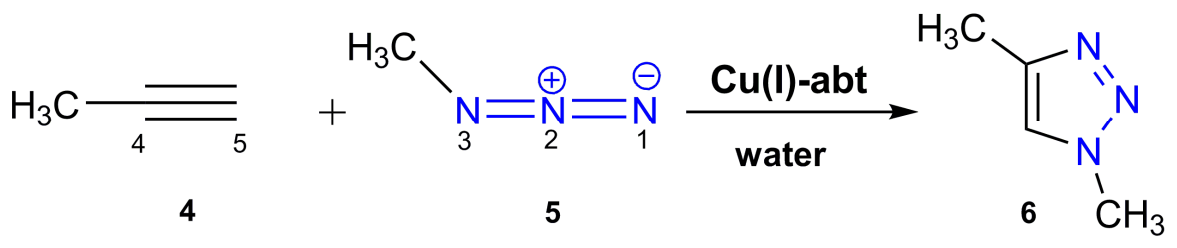

Scheme 4. CuAAC reaction between 4 and 5 catalyzed by $\mathrm{Cu}(\mathrm{I})$-abt complex.

Azide components (TACs) participate in the zw-type 32CA with high activation energies [48], which can be favored through a more polar process by the increase of the electrophilic and nucleophilic character of the reagents. Consequently, the 32CA reaction catalyzed by $\mathrm{Cu}(\mathrm{I})$-abt complex was analyzed using the global reactivity indices defined within Conceptual DFT (CDFT) $[49,50]$ and the results are shown in Table 5. Compound 4 was found as a marginal electrophile and a marginal nucleophile within the electrophilicity [51] and nucleophilicity scales [52], a feature that explains the non-participation of $\mathbf{4}$ in polar cycloaddition reactions. In contrast, compound $\mathbf{5}$ is a strong electrophile $(\omega=1.22 \mathrm{eV})$ and a moderate nucleophile $(\mathrm{N}=2.15 \mathrm{eV})$. However, the coordination of 4 to copper(I)-abt increases the values of the $\omega$ and $N$ indexes to 1.14 and $3.11 \mathrm{eV}$ being thus classified as both strong electrophile and nucleophile. Therefore, the CuAAC reactions of 5 with Ac are polar reactions due to the strong nucleophilic (Ac) and the strong electrophilic (5) characters (see Table 5).

Table 5. Global reactivity indices (in $\mathrm{eV}$ ) of the reagents involved in $\mathrm{CuAAC}$ reactions catalyzed by $\mathrm{Cu}(\mathrm{I})-\mathrm{abt}$.

\begin{tabular}{ccccc}
\hline Species & $\boldsymbol{\mu}$ & $\boldsymbol{\eta}$ & $\boldsymbol{\omega}$ & $\boldsymbol{N}$ \\
\hline Propyne (4) & -2.68 & 8.71 & 0.42 & 2.06 \\
Methyl azide (5) & -3.87 & 6.16 & 1.22 & 2.15 \\
$\mathrm{Cu}(\mathrm{I})$-acetylide (Ac) & -3.42 & 5.17 & 1.14 & 3.11 \\
\hline
\end{tabular}

Recently, a lot of studies of polar 32CA reactions have shown that the analysis of the electrophilic and nucleophilic Parr functions allows us to explain the experimentally observed regioselectivity [53]. Thus, the electrophilic $\mathrm{P}_{\mathrm{k}}{ }^{+}$and nucleophilic $\mathrm{P}_{\mathrm{k}}{ }^{-}$Parr functions at 4, 5 and Ac were analyzed (see Figure 2). The analysis of the nucleophilic $\mathrm{P}_{\mathrm{k}}{ }^{-}$Parr functions at 4 indicates that the terminal $\mathrm{C5}$ carbon is the most nucleophilic center of this molecule $\left(\mathrm{P}_{\mathrm{k}}{ }^{-}=0.54\right)$, although the $\mathrm{C} 4$ carbon is also nucleophilically activated $\left(\mathrm{P}_{\mathrm{k}}{ }^{-}=0.36\right)$. On the other hand, the analysis of the electrophilic $\mathrm{P}_{\mathrm{k}}{ }^{+}$ Parr functions at 5 reveals that the terminal N1 nitrogen is the most electrophilic center of this TAC $\left(\mathrm{P}_{\mathrm{k}}{ }^{+}=0.56\right)$. These results suggest that along with a polar 32CA reaction, the 1,5-regioisomer will be the main reaction product. However, the very low polar character of this non-catalyzed AAC reaction accounts for its low regioselectivity.
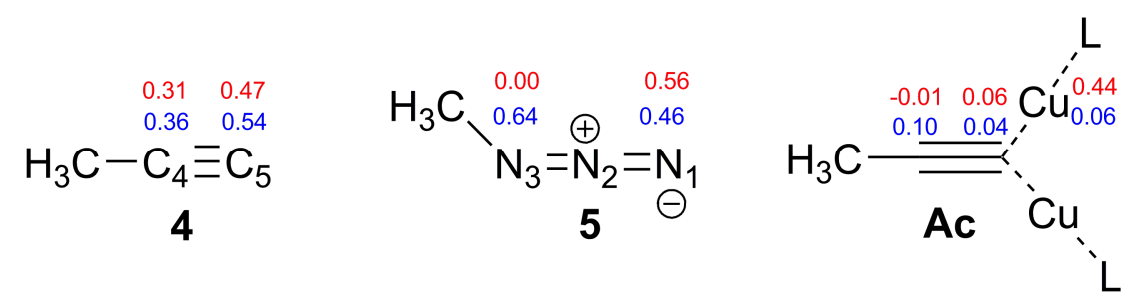

Figure 2. Electrophilic $\mathrm{P}_{\mathrm{k}}{ }^{+}$(red) and nucleophilic $\mathrm{P}_{\mathrm{k}}{ }^{-}$(blue) Parr functions at 4, 5 and $\mathrm{Ac}(\mathrm{L}=\mathrm{abt})$. 
Figure 3 shows electrophilic $\mathrm{P}_{\mathrm{k}}{ }^{+}$and nucleophilic $\mathrm{P}_{\mathrm{k}}{ }^{-}$Parr functions of 4, 5 and Ac. The analysis of the nucleophilic $\mathrm{P}_{\mathrm{k}}{ }^{-}$Parr functions at 4 indicates that the terminal carbon (C5) is the most nucleophilic center of this molecule $\left(\mathrm{P}_{\mathrm{k}}{ }^{-}=0.57\right)$, while the most electrophilic center of 5 is the terminal N1 nitrogen $\left(\mathrm{P}_{\mathrm{k}}{ }^{+}=0.57\right)$. Thus, the very low polar character of this non-catalyzed azide-alkyne cycloaddition reaction accounts for its low regioselectivity. The electrophilic Parr functions at Ac characterize the copper atom interacting with the abt ligand as the most electrophilic center $\left(\mathrm{P}_{\mathrm{k}}{ }^{+}=0.44\right)$, while the nucleophilic Parr functions at 5 points out the substituted N3 nitrogen atom as the most nucleophilic center $\left(\mathrm{P}_{\mathrm{k}}{ }^{-}=0.64\right)$. These results show that the most favorable interaction is the $\mathrm{Cu}-\mathrm{N}$ bond, conducting to the formation of a reactive complex (RC) (vide infra) and the increase in the electrophilicity value of the alkyne makes the use of the abt ligand in the CuAAC reactions more favorable.
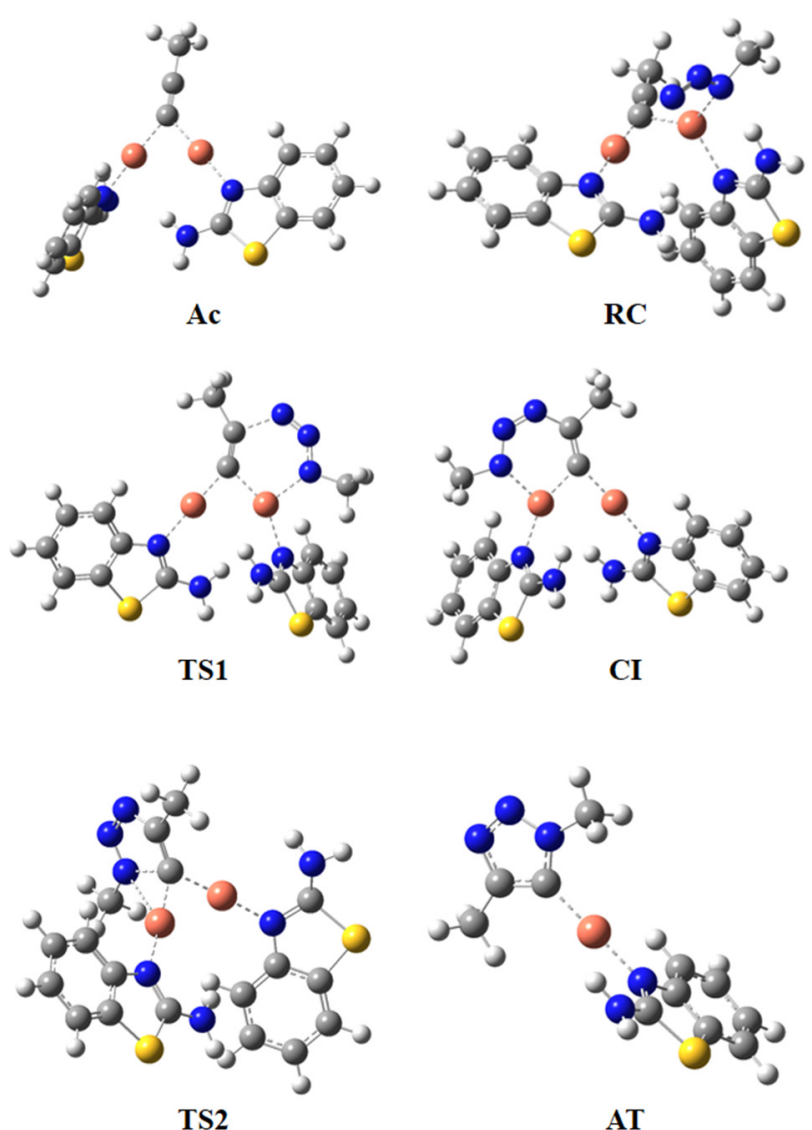

AT

Figure 3. Optimized geometries of the stationary points involved in the dinuclear CuAAC reaction of Ac with 5.

In the first step of the CuAAC mechanism, 4 binds to a copper(I) cation as a $\pi$-ligand. This coordination increases the acidity of the terminal alkyne, favoring the formation of mononuclear $\mathrm{Cu}(\mathrm{I})$-acetylide upon deprotonation. Then, the coordination of the $\mathrm{C} 5$ carbon atom to a second copper(I) center leads to the dinuclear Ac species. Subsequently, the coordination of 5 to a copper(I) cation in Ac via its N3 azide nitrogen allows the formation of the reactive complex (RC). This intermediate is the starting point for the stepwise sequences represented in Figure 3. This step is highly exothermic at $17.31 \mathrm{kcal} / \mathrm{mol}$. The computed barrier for the formation of the first N1-C4 single bond via TS1 is $2.66 \mathrm{kcal} / \mathrm{mol}$, a value which is smaller than the barrier for the non-catalyzed reaction (ca. $30.3 \mathrm{kcal} / \mathrm{mol}$ ) [54]. Subsequently, the formation of the intermediate complex (IC) is exothermic by ca. $13.74 \mathrm{kcal} / \mathrm{mol}$. From this intermediate, the barrier for the ring contraction leading to the $\mathrm{Cu}(\mathrm{I})$-triazolyl derivative is $11.17 \mathrm{kcal} / \mathrm{mol}$ (TS2). Finally, the formation of the AT derivative is exothermic by $112.14 \mathrm{kcal} / \mathrm{mol}$. These results allow us to explain the easy formation of the corresponding triazoles in water. Moreover, 
the use of abt as ligand for copper(I) in the CuAAC process shows that this heterocyclic ligand causes a decrease of the energy barrier of about $3-6 \mathrm{kcal} / \mathrm{mol}$ in the aqueous phase, by comparison with our previously reported catalytic system using the water molecule as the only ligand [55].

\subsubsection{ELF Topological Analysis}

In order to get more understanding of the $\mathrm{CuAAC}$ reactions catalyzed by $\mathrm{Cu}(\mathrm{I})$-abt, all intermediates in the reaction between Ac and 5 were characterized by a topological analysis of the ELF [56]. The results are given in Table 6 and the ELF-based Lewis representations are illustrated in Figure 4.

Table 6. ELF valence basin populations in the average number of electrons (e) of the intermediates involved in the CuAAC reaction of Ac with 5.

\begin{tabular}{cccccccc}
\hline Structures & $\mathbf{5}$ & Ac & RC & TS1 & Cl & TS2 & AT \\
\hline V(N1,N2) & 1.74 & - & 1.80 & 2.32 & 2.00 & 1.89 & 1.85 \\
$\mathrm{~V}^{\prime}(\mathrm{N} 1, N 2)$ & 2.22 & - & 1.83 & - & - & - & - \\
$\mathrm{V}(\mathrm{N} 2)$ & - & - & - & 2.60 & 2.84 & 2.82 & 3.34 \\
$\mathrm{~V}(\mathrm{~N} 2, \mathrm{~N} 3)$ & 2.51 & - & 2.51 & 1.65 & 1.78 & 2.01 & 1.58 \\
$\mathrm{~V}(\mathrm{C} 4, \mathrm{C} 5)$ & - & 2.38 & 2.41 & 1.96 & 3.35 & 2.90 & 3.09 \\
$\mathrm{~V}^{\prime}(\mathrm{C} 4, \mathrm{C} 5)$ & - & 2.39 & 2.34 & 1.98 & - & - & - \\
$\mathrm{V}(\mathrm{N} 3)$ & 3.53 & - & 3.58 & 1.99 & 1.85 & 2.99 & 0.79 \\
$\mathrm{~V}^{\prime}(\mathrm{N} 3)$ & - & - & - & 1.63 & 1.67 & - & 0.76 \\
$\mathrm{~V}(\mathrm{C} 4)$ & - & - & - & 0.39 & - & - & - \\
$\mathrm{V}(\mathrm{C} 5)$ & - & 3.37 & 3.45 & 2.34 & 3.00 & 2.21 & 3.21 \\
$\mathrm{~V}(\mathrm{~N} 1, \mathrm{C} 4)$ & - & - & - & - & 1.97 & 2.17 & 2.11 \\
$\mathrm{~V}(\mathrm{~N} 3, \mathrm{C} 5)$ & - & - & - & - & - & - & 2.20 \\
\hline
\end{tabular}<smiles>C=[N+]=NN</smiles>

5

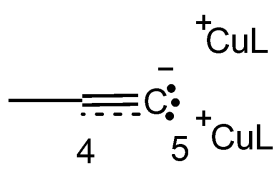

Ac<smiles>C[C+]#CC(C)=NN=NC</smiles>

CI<smiles>[CH]=NN=[N+]C</smiles><smiles>CC#[14CH]</smiles>

RC<smiles></smiles>

TS2<smiles>CC=CC#N</smiles>

TS1<smiles>Cc1n[nH]n(C)c1=[W]Cl</smiles>

AT

Figure 4. ELF-based Lewis structures of the intermediates involved in the CuAAC reaction of Ac with $5(\mathrm{~L}=\mathrm{abt})$.

The topological analysis of the ELF of 5 is characterized by the presence of two V(N1,N2) and $\mathrm{V}^{\prime}(\mathrm{N} 1, \mathrm{~N} 2)$ disynaptic basins integrating a total population of $4.00 \mathrm{e}$, two $\mathrm{V}(\mathrm{N} 1)$ and $\mathrm{V}(\mathrm{N} 3)$ monosynaptic basins integrating 3.94 and 3.53 e and one $\mathrm{V}(\mathrm{N} 2, \mathrm{~N} 3)$ disynaptic basin integrating 2.51 e. Accordingly, Lewis' bonding model for 5 is identified by one N1-N2 double bond, a N2-N3 single bond and two lone pairs at the N1 and N3 azide-nitrogen atoms (see Table 6 and Figure 4), confirming that 5 participates as zwitterionic TAC in the 32CA reactions [57]. The electronic structure of Ac shows the presence of one $\mathrm{V}(\mathrm{C} 5)$ monosynaptic basin, with a high electron population of $3.37 \mathrm{e}$ and two $\mathrm{V}(\mathrm{C} 4, \mathrm{C} 5)$ and $\mathrm{V}^{\prime}(\mathrm{C} 4, \mathrm{C} 5)$ 
disynaptic basins, with a total population of $4.75 \mathrm{e}$. These valence basins can be attributed to the $\mathrm{C} 4-\mathrm{C} 5$ double bond and the $\mathbf{C} 5$ carbanionic center, reveals the ionic nature of Ac (see Table 6 and Figure 4).

The ELF analysis for the reactive complex (RC) shows non-appreciable topological changes with respect to the separated reagents. For example, a similar behavior is located at the azide framework for the $\mathrm{V}(\mathrm{N} 2, \mathrm{~N} 3)$ disynaptic basin and the total population of the $\mathrm{V}(\mathrm{N} 1, \mathrm{~N} 2)$ and $\mathrm{V}^{\prime}(\mathrm{N} 1, \mathrm{~N} 2)$ disynaptic basins increases by an equivalent amount. A similar behavior is found for the two $V(N 1)$ and V(N3) monosynaptic basins. The $\mathrm{V}(\mathrm{C} 4, \mathrm{C} 5)$ and $\mathrm{V}^{\prime}(\mathrm{C} 4, \mathrm{C} 5)$ disynaptic basins in the alkyne framework are slightly depopulated by 0.03 and $0.05 \mathrm{e}$, respectively. Several changes occur in the azide framework at TS1, while a new V(N2) monosynaptic basin, associated with the N2 nitrogen non-bonding electron density, was created, integrating $2.60 \mathrm{e}$. The total population of the $\mathrm{V}(\mathrm{N} 2, \mathrm{~N} 3)$ disynaptic basin, as well as that of the two $\mathrm{V}(\mathrm{N} 1, \mathrm{~N} 2)$ and $\mathrm{V}^{\prime}(\mathrm{N} 1, \mathrm{~N} 2)$ disynaptic basins, strongly decreased by 0.86 and $1.64 \mathrm{e}$, respectively. In addition, the $\mathrm{V}(\mathrm{N} 3)$ monosynaptic basin split into two $\mathrm{V}(\mathrm{N} 3)$ and $\mathrm{V}^{\prime}(\mathrm{N} 3)$ monosynaptic basins integrating 1.99 and $1.63 \mathrm{e}$, although their total population only increased by 0.04 e. Otherwise, the population of the $\mathrm{V}(\mathrm{N} 1)$ monosynaptic basin more markedly increased to $3.62 \mathrm{e}$, but the N1 nitrogen non-bonding electron density remained characterized by one single V(N1) monosynaptic basin. A strong depopulation of the two $\mathrm{V}(\mathrm{C} 4, \mathrm{C} 5)$ and $\mathrm{V}^{\prime}(\mathrm{C} 4, \mathrm{C} 5)$ disynaptic basins was achieved for the acetylide framework by a total of $0.81 \mathrm{e}$. The $\mathrm{V}(\mathrm{C} 5)$ monosynaptic basin reached $2.34 \mathrm{e}$ and a new $\mathrm{V}(\mathrm{C} 4)$ monosynaptic basin was created integrating $0.39 \mathrm{e}$, which can be attributed to a $\mathrm{C} 4$ pseudoradical center. At $\mathrm{CI}$, a new $\mathrm{V}(\mathrm{N} 1, \mathrm{C} 4)$ disynaptic basin is observed integrating $1.97 \mathrm{e}$ and the disappearance of the $\mathrm{V}(\mathrm{C} 4)$ monosynaptic basin located at TS1, which is related to the new N1-C4 single bond by sharing part of the electron population of the $\mathrm{V}(\mathrm{N} 1)$ monosynaptic basin and that of the $\mathrm{V}(\mathrm{C} 4)$ one (Table 6). At TS2, the most relevant topological change is the merging of the two V(N3) and $\mathrm{V}^{\prime}(\mathrm{N} 3)$ monosynaptic basins into one single $\mathrm{V}(\mathrm{N} 3)$ monosynaptic basin $3.50 \mathrm{e}$, with respect to the ELF topological characterization of CI. In addition, a slight depopulation of 0.13 e towards the $\mathrm{V}(\mathrm{N} 2, \mathrm{~N} 3)$ disynaptic basin, increasing to 2.01 e also occurred. It was also found that the population of the $\mathrm{V}(\mathrm{C} 5)$ monosynaptic basin, which was decreased at TS1, has decreased to 3.00 e. Finally, at AT, a new disynaptic basin $\mathrm{V}(\mathrm{N} 3, \mathrm{C} 5)$ was observed integrating 2.20 e. The creation of this disynaptic basin, which is associated to the new N3-C5 single bond, was accompanied by a notable depopulation of the $\mathrm{V}(\mathrm{N} 3)$ by $2.20 \mathrm{e}$ and the increasing of the total population of $\mathrm{V}(\mathrm{C} 5)$ monosynaptic basins by $1.00 \mathrm{e}$. These results suggest that the creation of the $\mathrm{V}(\mathrm{N} 3, \mathrm{C} 5)$ disynaptic basin took place by displacement of part of the electron populations of both $\mathrm{V}(\mathrm{N} 3)$ to $\mathrm{V}(\mathrm{C} 5)$ monosynaptic basins. On the other hand, the two $\mathrm{V}(\mathrm{N} 1, \mathrm{~N} 2)$ and $\mathrm{V}(\mathrm{N} 2, \mathrm{~N} 3)$ disynaptic basins in the azide framework have decreased to less than $2 \mathrm{e}$ and the $\mathrm{V}(\mathrm{N} 2)$ monosynaptic basins integrates $3.34 \mathrm{e}$. All these results show that the ionic nature of all chemical intermediates rules out any covalent interaction involving the copper(I)-complexes, as supported by the ELF topological analysis, reaffirming the zw-type mechanism of the $\mathrm{Cu}(\mathrm{I})$-abt complex catalyzed AAC reactions.

\section{Materials and Methods}

\subsection{Materials}

All chemicals and reagents employed in this work were purchased from Sigma Aldrich and all organic solvents were used without additional purification. The reactions were monitored by thin-layer chromatography (TLC) carried out on commercial glass-backed TLC plates (aluminum plates coated with silica gel 60 F254, $0.25 \mathrm{~mm}$ thickness, Merck).

FT-IR spectra were performed on a FTIR spectrophotometer (FT-IR Nicolet 5700, ThermoFischer, Madrid, Spain). The NMR spectra were recorded on a BRUKER DRX-300 AVANCE spectrometer in $\mathrm{CDCl}_{3}$ using the tetramethylsilane (TMS) as an internal standard. 


\subsection{Synthesis of $\left[\mathrm{Cu}(\mathrm{abt})_{2}\left(\mathrm{OOCCH}_{3}\right)_{2}\right](1)$}

In a typical experiment, $0.10 \mathrm{~g}$ of abt was dissolved in $10 \mathrm{~mL}$ of methanol then $5 \mathrm{~mL}$ of $\mathrm{Cu}(\mathrm{OAc})_{2}$ water solution $\left(2 \times 10^{-2} \mathrm{M}\right)$ was added slowly under continuous stirring at room temperature. The solution took a green color during the addition of the copper(II) acetate solution. A precipitate was formed and the mixture was stirred for $12 \mathrm{~h}$ at room temperature. The solid was filtered, washed with water and dried at $40{ }^{\circ} \mathrm{C}$ overnight to afford complex 1 as a green solid (Yield: $88 \%$ ). FT-IR data $\left(\mathrm{KBr} / \mathrm{cm}^{-1}\right): 3396\left[v\left(\mathrm{NH}_{2}\right)\right], 1623[v(\mathrm{C}=\mathrm{N})], 1342[v(\mathrm{C}-\mathrm{O})], 1592$ and $1529\left[v(\mathrm{C}=\mathrm{N})_{\mathrm{ar}}+v(\mathrm{C}=\mathrm{C})_{a r}\right]$, 1467 and $1435[v(\mathrm{C}-\mathrm{N})\}, 508[v(\mathrm{Cu}-\mathrm{O})]$ and $689[v(\mathrm{Cu}-\mathrm{N})]$.

\subsection{General Procedure for the CuAAC Reaction}

Azides $(0.6 \mathrm{mmol})$, alkynes $(0.5 \mathrm{mmol})$ and complex $1(2 \mathrm{~mol} \%)$ were mixed with water $(3 \mathrm{~mL})$ and stirred at room temperature. After completion of the catalytic cycloaddition reaction, as confirmed by TLC analysis, the reaction mixture was diluted with diethyl ether and extracted three times. The combined organic layers were then concentrated under reduced pressure to give the corresponding triazole derivatives that were purified by simple recrystallization, if needed.

The reaction mixture was stirred at room temperature and the reaction was monitored through thin layer chromatography. After completion, the reaction mixture was diluted by diethyl ether and the combined organic layers were then concentrated under vacuum to give the corresponding triazole derivatives and, if required, the products were purified by recrystallization.

\subsubsection{Synthesis of 1-Benzyl-4-phenyl-1H-1,2,3-triazole (3a)}

White solid. ${ }^{1} \mathrm{H}$ NMR $\left(300 \mathrm{MHz}, \mathrm{CDCl}_{3}, \delta \mathrm{ppm}\right): 5.59\left(\mathrm{~s}, 2 \mathrm{H}, \mathrm{CH}_{2}\right), 7.31-7.44\left(\mathrm{~m}, 8 \mathrm{H}, \mathrm{CH}_{\mathrm{ar}}\right)$, $7.69\left(\mathrm{~s}, 1 \mathrm{H}, \mathrm{CH}_{\text {triazole }}\right), 7.81-7.83\left(\mathrm{~s}, 2 \mathrm{H}, \mathrm{CH}_{\mathrm{ar}}\right) .{ }^{13} \mathrm{C} \mathrm{NMR}\left(75 \mathrm{MHz}, \mathrm{CDCl}_{3}, \delta \mathrm{ppm}\right): 54.6\left(\mathrm{CH}_{2}\right)$, 120.0 $\left(\mathrm{CH}_{\mathrm{ar}}\right), 126.1\left(\mathrm{CH}_{\mathrm{ar}}\right), 128.5\left(2 \times \mathrm{CH}_{\mathrm{ar}}\right), 128.6\left(2 \times \mathrm{CH}_{\mathrm{ar}}\right), 129.2\left(\mathrm{C}_{\mathrm{ar}}\right), 129.6\left(\mathrm{CH}_{\text {triazole }}\right), 131.0\left(\mathrm{C}_{\mathrm{ar}}\right)$, $135.1\left(\mathrm{C}_{\mathrm{ar}}\right)$. HRMS (ESI) $[\mathrm{M}+\mathrm{H}]+$ found $\mathrm{m} / \mathrm{z}=236.1183$. Calcd value for $\mathrm{C}_{15} \mathrm{H}_{13} \mathrm{~N}_{3}=236.1182$.

\subsubsection{Synthesis of 1- Benzyl-4-p-Tolyl-1H-1,2,3-Triazole (3b)}

White solid. ${ }^{1} \mathrm{H}$ NMR (300 MHz, $\left.\mathrm{CDCl}_{3}, \delta \mathrm{ppm}\right): 2.38\left(\mathrm{~s}, 3 \mathrm{H}, \mathrm{CH}_{3}\right), 5.59\left(\mathrm{~s}, 2 \mathrm{H}, \mathrm{CH}_{2}\right), 7.22-7.42$ (m, 7H, $\left.\mathrm{CH}_{\mathrm{ar}}\right), 7.66\left(\mathrm{~s}, 1 \mathrm{H}, \mathrm{CH}_{\text {triazole }}\right), 7.70-7.73\left(\mathrm{~d}, 2 \mathrm{H}, \mathrm{CH}_{\mathrm{ar}}\right) .{ }^{13} \mathrm{C} \mathrm{NMR}(75 \mathrm{MHz}, \mathrm{CDCl} 3, \delta \mathrm{ppm})$ : $21.7\left(\mathrm{CH}_{3}\right), 54.6\left(\mathrm{CH}_{2}\right), 126.0\left(\mathrm{CH}_{\mathrm{ar}}\right), 128.2\left(2 \times \mathrm{CH}_{\mathrm{ar}}\right), 128.5\left(2 \times \mathrm{CH}_{\mathrm{ar}}\right), 129.2\left(2 \times \mathrm{CH}_{\mathrm{ar}}\right), 129.6\left(2 \times \mathrm{CH}_{\mathrm{ar}}\right)$, $129.9\left(\mathrm{C}_{\mathrm{ar}}\right), 131.7\left(\mathrm{CH}_{\text {triazole }}\right), 135.2\left(2 \mathrm{C}_{\mathrm{ar}}\right), 138.4\left(\mathrm{C}_{\text {triazole }}\right)$. HRMS (ESI) $[\mathrm{M}+\mathrm{H}]^{+}$found $\mathrm{m} / z=250.1339$. Calcd value for $\mathrm{C}_{16} \mathrm{H}_{15} \mathrm{~N}_{3}=250.1339$.

\subsubsection{Synthesis of 1-(4-Methylbenzyl)-4-Phenyl-1H-1,2,3-Triazole (3c)}

White solid. ${ }^{1} \mathrm{H}$ NMR (300 MHz, $\mathrm{CDCl}_{3}, \delta \mathrm{ppm}$ ): 2.28 (s, 3H, $\left.\mathrm{CH}_{3}\right) ; 5.46\left(\mathrm{~s}, 2 \mathrm{H}, \mathrm{CH}_{2}\right) ; 7.13-7.35$ (m, 7H, CHar $) ; 7.57\left(\mathrm{~s}, 1 \mathrm{H}, \mathrm{CH}_{\text {triazole }}\right) ; 7.71-7.73\left(\mathrm{~d}, 2 \mathrm{H}, \mathrm{CH}_{\mathrm{ar}}\right) .{ }^{13} \mathrm{C} \mathrm{NMR}\left(75 \mathrm{MHz}, \mathrm{CDCl}_{3}, \delta \mathrm{ppm}\right)$ : $21.2\left(\mathrm{CH}_{3}\right) ; 54.1\left(\mathrm{CH}_{2}\right) ; 125.70\left(2 \mathrm{CH}_{\mathrm{ar}}\right) ; 128.2\left(3 \times \mathrm{CH}_{\mathrm{ar}}\right) ; 129.8\left(4 \times \mathrm{CH}_{\mathrm{ar}}\right) ; 129.8\left(\mathrm{C}_{\mathrm{ar}}\right) ; 130.6\left(\mathrm{CH}_{\text {triazole }}\right) ;$ $131.6\left(\mathrm{C}_{\mathrm{ar}}\right) ; 138.8\left(\mathrm{C}_{\mathrm{ar}}\right) ; 148.7\left(\mathrm{C}_{\text {triazole }}\right)$. HRMS (ESI) $[\mathrm{M}+\mathrm{H}]^{+}$found $m / z=250.1345$. Calcd value for $\mathrm{C}_{16} \mathrm{H}_{15} \mathrm{~N}_{3}=250.1344$.

\subsubsection{Synthesis of 1-Benzyl-4-(Phenoxymethyl)-1H-1,2,3-Triazole (3d)}

White solid. ${ }^{1} \mathrm{H}$ NMR (300 MHz, $\mathrm{CDCl}_{3}, \delta$ ppm): 5.21 (s, 2H, $\left.\mathrm{CH}_{2}\right) ; 5.55$ (s, 2H,OCH$\left.)_{2}\right) ; 6.96-7.00$ $\left(\mathrm{m}, 3 \mathrm{H}, \mathrm{CH}_{\mathrm{ar}}\right) ; 7.28-7.41\left(\mathrm{~m}, 7 \mathrm{H}, \mathrm{CH}_{\mathrm{ar}}\right) ; 7.57\left(\mathrm{~s}, 1 \mathrm{H}, \mathrm{CH}_{\text {triazole }}\right) .{ }^{13} \mathrm{C} \mathrm{NMR}\left(75 \mathrm{MHz}, \mathrm{CDCl}_{3}, \delta \mathrm{ppm}\right)$ : $54.7\left(\mathrm{CH}_{2}\right) ; 62.5\left(\mathrm{CH}_{2}\right) ; 115.2\left(2^{*} \mathrm{CH}_{\mathrm{ar}}\right) ; 116.2\left(\mathrm{CH}_{\mathrm{ar}}\right) ; 121.7\left(\mathrm{CH}_{\text {triazole }}\right) ; 128.6\left(\mathrm{CH}_{\mathrm{ar}}\right) ; 129.22\left(2 \mathrm{CH}_{\mathrm{ar}}\right)$; $129.5\left(4 \mathrm{CH}_{\mathrm{ar}}\right) ; 129.9\left(\mathrm{C}_{\mathrm{ar}}\right) ; 134.9\left(\mathrm{C}_{\text {triazole }}\right) ; 158.6\left(\mathrm{C}_{\mathrm{ar}}\right)$. HRMS (ESI) $[\mathrm{M}+\mathrm{H}]^{+}$found $m / z=266.1289$. Calcd value for $\mathrm{C}_{16} \mathrm{H}_{15} \mathrm{~N}_{3} \mathrm{O}=266.1288$. 


\subsubsection{Synthesis of 1-(4-Fluoro-Benzyl)-4-p-Tolyl-1H-[1,2,3]Triazole (3e)}

White solid. ${ }^{1} \mathrm{H}$ NMR (300 MHz, $\left.\mathrm{CDCl}_{3}, \delta \mathrm{ppm}\right): 2.39\left(\mathrm{~s}, 3 \mathrm{H}, \mathrm{CH}_{3}\right) ; 5.55\left(\mathrm{~s}, 2 \mathrm{H}, \mathrm{CH}_{2}\right)$; 7.06-7.17 (m, 2H, $\left.\mathrm{CH}_{\mathrm{ar}}\right) ; 7.22-7.29\left(\mathrm{~m}, 2 \mathrm{H}, \mathrm{CH}_{\mathrm{ar}}\right) ; 7.39-7.45\left(\mathrm{~m}, 2 \mathrm{H}, \mathrm{CH}_{\mathrm{ar}}\right) ; 7.64\left(\mathrm{~s}, 1 \mathrm{H}, \mathrm{CH}_{\text {triazole }}\right)$; 7.69-7.72 (m, 2H, $\left.\mathrm{CH}_{\mathrm{ar}}\right) .{ }^{13} \mathrm{C} \mathrm{NMR}\left(75 \mathrm{MHz}, \mathrm{CDCl}_{3}, \delta \mathrm{ppm}\right): 21.3\left(\mathrm{CH}_{3}\right) ; 53.5\left(\mathrm{CH}_{2}\right) ; 116.0\left(\mathrm{CH}_{\mathrm{ar}}\right)$; $116.3\left(\mathrm{CH}_{\mathrm{ar}}\right) ; 119.1\left(\mathrm{CH}_{\mathrm{ar}}\right) ; 125.62\left(\mathrm{CH}_{\mathrm{ar}}\right) ; 127.63\left(\mathrm{C}_{\mathrm{ar}}\right) ; 129.52\left(2 \times \mathrm{CH}_{\mathrm{ar}}\right) ; 129.88\left(\mathrm{CH}_{\mathrm{ar}}\right) ; 129.99\left(\mathrm{CH}_{\mathrm{ar}}\right)$; $130.62\left(\mathrm{CH}_{\text {triazole }}\right) ; 130.7\left(2 \mathrm{CH}_{\mathrm{ar}}\right) ; 138.1\left(2 \mathrm{C}_{\mathrm{ar}}\right) ; 148.5\left(\mathrm{C}_{\text {triazole }}\right) ; 161.2\left(\mathrm{C}_{\mathrm{ar}}-\mathrm{F}\right)$. HRMS (ESI) $[\mathrm{M}+\mathrm{H}]^{+}$ found $m / z=268.1249$. Calcd value for $\mathrm{C}_{16} \mathrm{H}_{14} \mathrm{FN}_{3}=268.1245$.

\subsubsection{Synthesis of 1-(4-Fluorobenzyl)-4-(4-Fluorophenyl)-1H-1,2,3-Triazole (3f)}

White solid. ${ }^{1} \mathrm{H}$ NMR (300 MHz, $\mathrm{CDCl}_{3}, \delta$ ppm): 5.55 (s, 2H, $\left.\mathrm{CH}_{2}\right) ; 7.08-7.15\left(\mathrm{~m}, 4 \mathrm{H}, \mathrm{CH}_{\mathrm{ar}}\right)$; 7.31-7.36 (m, 2H, CH $\left.\mathrm{CH}_{\mathrm{ar}}\right) ; 7.63\left(\mathrm{~s}, 1 \mathrm{H}, \mathrm{CH}_{\text {triazole }}\right) ; 7.77-7.82\left(\mathrm{~m}, 2 \mathrm{H}, \mathrm{CH}_{\mathrm{ar}}\right) .{ }^{13} \mathrm{C} \mathrm{NMR}\left(75 \mathrm{MHz}, \mathrm{CDCl}_{3}\right.$, $\delta$ ppm): $53.6\left(\mathrm{CH}_{2}\right) ; 115.7\left(\mathrm{CH}_{\mathrm{ar}}\right) ; 116.0\left(\mathrm{CH}_{\mathrm{ar}}\right) ; 116.1\left(\mathrm{CH}_{\mathrm{ar}}\right) ; 116.4\left(\mathrm{CH}_{\mathrm{ar}}\right) ; 119.0\left(\mathrm{C}_{\text {triazole }}\right) ; 127.4\left(\mathrm{C}_{\mathrm{ar}}\right)$; $127.5\left(2 \times \mathrm{CH}_{\mathrm{ar}}\right) ; 129.9\left(2 \times \mathrm{CH}_{\mathrm{ar}}\right) ; 130.0\left(\mathrm{C}_{\mathrm{ar}}\right) ; 137.8\left(\mathrm{CH}_{\text {triazole }}\right) ; 161.5\left(\mathrm{C}_{\mathrm{ar}}-\mathrm{F}\right) ; 163.5\left(\mathrm{C}_{\mathrm{ar}}-\mathrm{F}\right)$. HRMS (ESI) $[\mathrm{M}+\mathrm{H}]^{+}$found $m / z=272.0996$. Calcd value for $\mathrm{C}_{15} \mathrm{H}_{11} \mathrm{~F}_{2} \mathrm{~N}_{3}=272.0994$.

\subsubsection{Synthesis of (1-(4-Isopropylphenyl)-1H-1,2,3-Triazol-4-yl)Methyl Benzoate (3g)}

White solid. ${ }^{1} \mathrm{H}$ NMR (300 MHz, $\mathrm{CDCl}_{3}, \delta$ ppm): 1.29 (s, 3H, $\left.\mathrm{CH}_{3}\right) ; 1.31\left(\mathrm{~s}, 3 \mathrm{H}, \mathrm{CH}_{3}\right) ; 2.95-3.04$ $(\mathrm{m}, 1 \mathrm{H}, \mathrm{CH}) ; 5.58\left(\mathrm{~s}, 2 \mathrm{H}, \mathrm{CH}_{2}\right) ; 7.37-7.40\left(\mathrm{~d}, 2 \mathrm{H}, \mathrm{CH}_{\mathrm{ar}}\right) ; 7.43-7.48\left(\mathrm{t}, 2 \mathrm{H}, \mathrm{CH}_{\mathrm{ar}}\right) ; 7.56-7.60(\mathrm{~d}, 1 \mathrm{H}$, $\left.\mathrm{CH}_{\mathrm{ar}}\right) ; 7.64-7.67\left(\mathrm{~d}, 2 \mathrm{H}, \mathrm{CH}_{\mathrm{ar}}\right) ; 8.07-8.10\left(\mathrm{~d}, 2 \mathrm{H}, \mathrm{CH}_{\mathrm{ar}}\right) ; 8.12\left(\mathrm{~s}, 1 \mathrm{H}, \mathrm{CH}_{\text {triazole }}\right) .{ }^{13} \mathrm{C} \mathrm{NMR}(75 \mathrm{MHz}$, $\left.\mathrm{CDCl}_{3}, \delta \mathrm{ppm}\right): 24.3\left(2 \times \mathrm{CH}_{3}\right) ; 34.2(\mathrm{CH}) ; 58.5\left(\mathrm{CH}_{2}\right) ; 121.1\left(\mathrm{CH}_{\text {triazole }}\right) ; 122.7\left(\mathrm{C}_{\mathrm{ar}}\right) ; 128.1\left(2 \times \mathrm{CH}_{\mathrm{ar}}\right)$; $128.8\left(2 \times \mathrm{CH}_{\mathrm{ar}}\right) ; 130.1\left(2 \times \mathrm{CH}_{\mathrm{ar}}\right) ; 130.2\left(2 \times \mathrm{CH}_{\mathrm{ar}}\right) ; 133.7\left(\mathrm{C}_{\mathrm{ar}}\right) ; 135.2\left(\mathrm{CH}_{\mathrm{ar}}\right) ; 143.8\left(\mathrm{C}_{\text {triazole }}\right) ; 150.4\left(\mathrm{C}_{\mathrm{ar}}\right)$; $166.9\left(\mathrm{C}_{\text {ester }}\right.$ ). HRMS (ESI) $[\mathrm{M}+\mathrm{H}]^{+}$found $m / z=322.1562$. Calcd value for $\mathrm{C}_{19} \mathrm{H}_{19} \mathrm{~N}_{3} \mathrm{O}_{2}=322.1550$.

\subsubsection{Synthesis of Methyl 1-(4-Isopropylphenyl)-1H-1,2,3-Triazole-4-Carboxylate (3h)}

White solid. ${ }^{1} \mathrm{H}$ NMR (300 MHz, $\left.\mathrm{CDCl}_{3}, \delta \mathrm{ppm}\right): 1.30\left(\mathrm{~s}, 3 \mathrm{H}, \mathrm{CH}_{3}\right) ; 1.32\left(\mathrm{~s}, 3 \mathrm{H}, \mathrm{CH}_{3}\right) ; 2.97-3.06(\mathrm{~m}$, $1 \mathrm{H}, \mathrm{CH}) ; 4.01\left(\mathrm{~s}, 3 \mathrm{H}, \mathrm{OCH}_{3}\right) ; 7.40-7.43\left(\mathrm{~d}, 2 \mathrm{H}, \mathrm{CH}_{\mathrm{ar}}\right) ; 7.66-7.70\left(\mathrm{~d}, 2 \mathrm{H}, \mathrm{CH}_{\mathrm{Ar}}\right) ; 8.50\left(\mathrm{~s}, 1 \mathrm{H}, \mathrm{CH}_{\text {triazole }}\right)$. ${ }^{13} \mathrm{C} \mathrm{NMR}\left(75 \mathrm{MHz}, \mathrm{CDCl}_{3}, \delta \mathrm{ppm}\right): 24.2\left(2 * \mathrm{CH}_{3}\right) ; 34.3(\mathrm{CH}) ; 52.7\left(\mathrm{OCH}_{3}\right) ; 121.3\left(\mathrm{C}_{\mathrm{ar}}\right) ; 126.0\left(2 \times \mathrm{CH}_{\mathrm{ar}}\right)$; $128.3\left(\mathrm{CH}_{\text {triazole }}\right) ; 134.7\left(2 \times \mathrm{CH}_{\mathrm{ar}}\right) ; 141.3\left(\mathrm{C}_{\text {triazole }}\right) ; 151.2\left(\mathrm{C}_{\mathrm{ar}}\right) ; 161.6\left(\mathrm{C}_{\text {ester }}\right)$. HRMS (ESI) $[\mathrm{M}+\mathrm{H}]^{+}$ found $m / z=246.1239$. Calcd value for $\mathrm{C}_{13} \mathrm{H}_{15} \mathrm{~N}_{3} \mathrm{O}_{2}=246.1237$.

\subsubsection{Synthesis of 1-(4-Isopropylphenyl)-4-(Phenylthiomethyl)-1H-1,2,3-Triazole (3i)}

White solid. ${ }^{1} \mathrm{H}$ NMR (300 MHz, $\mathrm{CDCl}_{3}, \delta$ ppm): 1.29 (s, 3H, $\left.\mathrm{CH}_{3}\right) ; 1.31\left(\mathrm{~s}, 3 \mathrm{H}, \mathrm{CH}_{3}\right) ; 2.94-3.03(\mathrm{~m}$, $1 \mathrm{H}, \mathrm{CH}) ; 4.34\left(\mathrm{~s}, 2 \mathrm{H}, \mathrm{CH}_{2}\right) ; 7.19-7.24\left(\mathrm{~d}, 1 \mathrm{H}, \mathrm{CH}_{\mathrm{ar}}\right) ; 7.31-7.41\left(\mathrm{~m}, 6 \mathrm{H}, \mathrm{CH}_{\mathrm{ar}}\right) ; 7.57-7.61\left(\mathrm{~d}, 2 \mathrm{H}, \mathrm{CH}_{\mathrm{ar}}\right)$; $7.78\left(\mathrm{~s}, 1 \mathrm{H}, \mathrm{CH}_{\text {triazole }}\right) .{ }^{13} \mathrm{C} \mathrm{NMR}\left(75 \mathrm{MHz}, \mathrm{CDCl}_{3}, \delta \mathrm{ppm}\right): 24.3\left(2 \times \mathrm{CH}_{3}\right) ; 29.3(\mathrm{CH}) ; 34.2\left(\mathrm{CH}_{2}\right)$; $121.0\left(\mathrm{CH}_{\text {triazole }}\right) ; 126.59\left(\mathrm{CH}_{\mathrm{ar}}\right) ; 126.98\left(2 \times \mathrm{CH}_{\mathrm{ar}}\right) ; 128.06\left(2 * \mathrm{CH}_{\mathrm{ar}}\right) ; 129.45\left(2 \times \mathrm{CH}_{\mathrm{ar}}\right) ; 130.03\left(\mathrm{C}_{\text {triazole }}\right)$; $133.76\left(\mathrm{C}_{\mathrm{ar}}\right) ; 134.6\left(2 \times \mathrm{CH}_{\mathrm{ar}}\right) ; 135.8\left(\mathrm{C}_{\mathrm{ar}}\right) ; 150.2\left(\mathrm{C}_{\mathrm{ar}}\right)$. HRMS (ESI) $[\mathrm{M}+\mathrm{H}]^{+}$found $m / z=310.1373$. Calcd value for $\mathrm{C}_{18} \mathrm{H}_{19} \mathrm{~N}_{3} \mathrm{~S}=310.1372$.

\subsubsection{Synthesis of (1-(4-Methoxyphenyl)-1H-1,2,3-Triazol-4-yl)Methyl Benzoate (3j)}

White solid. ${ }^{1} \mathrm{H}$ NMR $\left(300 \mathrm{MHz}, \mathrm{CDCl}_{3}, \delta \mathrm{ppm}\right): 3.79\left(\mathrm{~s}, 3 \mathrm{H}, \mathrm{CH}_{3}\right), 5.48\left(\mathrm{~s}, 2 \mathrm{H}, \mathrm{CH}_{2}\right), 6.94(\mathrm{~d}, 1 \mathrm{H}$, $\left.\mathrm{CH}_{\mathrm{ar}}\right), 6.96\left(\mathrm{~d}, 1 \mathrm{H}, \mathrm{CH}_{\mathrm{ar}}\right), 7.36\left(\mathrm{t}, 1 \mathrm{H}, \mathrm{CH}_{\mathrm{ar}}\right), 7.47\left(\mathrm{t}, 1 \mathrm{H}, \mathrm{CH}_{\mathrm{ar}}\right), 7.49\left(\mathrm{~s}, 1 \mathrm{H}, \mathrm{CH}_{\text {triazole }}\right), 7.52\left(\mathrm{t}, 1 \mathrm{H}, \mathrm{CH}_{\mathrm{ar}}\right)$, $7.54\left(\mathrm{~d}, 1 \mathrm{H}, \mathrm{CH}_{\mathrm{ar}}\right), 7.56\left(\mathrm{~d}, 1 \mathrm{H}, \mathrm{CH}_{\mathrm{ar}}\right), 7.58\left(\mathrm{~d}, 1 \mathrm{H}, \mathrm{CH}_{\mathrm{ar}}\right), 8.0\left(\mathrm{~d}, 1 \mathrm{H}, \mathrm{CH}_{\mathrm{ar}}\right) .{ }^{13} \mathrm{C} \mathrm{NMR}\left(75 \mathrm{MHz}, \mathrm{CDCl}_{3}\right.$, $\delta$ ppm): $55.7\left(\mathrm{CH}_{3}\right), 58.1\left(\mathrm{CH}_{2}\right), 114.8\left(2 \times \mathrm{CH}_{\mathrm{ar}}\right), 122.3\left(2 \times \mathrm{CH}_{\mathrm{ar}}\right), 128.4\left(2 \times \mathrm{CH}_{\mathrm{ar}}\right), 129.7\left(3 \times \mathrm{CH}_{\mathrm{ar}}\right)$, $129.8(\mathrm{Cq}), 133.3\left(\mathrm{CH}_{\text {triazole }}\right), 136.0(\mathrm{Cq}), 151.3(\mathrm{Cq}), 160.0(\mathrm{Cq}), 166.6\left(\mathrm{C}_{\text {carbonyl }}\right)$. HRMS (ESI) $[\mathrm{M}+\mathrm{H}]^{+}$ found $m / z=310.1198$. Calcd value for $\mathrm{C}_{17} \mathrm{H}_{15} \mathrm{~N}_{3} \mathrm{O}_{3}=310.1186$.

\subsubsection{Synthesis of Naphthalen-2-yl 1-Benzyl-1H-1,2,3-Triazole-4-Carboxylate (3k)}

White solid. ${ }^{1} \mathrm{H}$ NMR (300 MHz, $\left.\mathrm{CDCl}_{3}, \delta \mathrm{ppm}\right): 5.57\left(\mathrm{~s}, 2 \mathrm{H}, \mathrm{CH}_{2}\right) ; 7.19\left(\mathrm{~s}, 1 \mathrm{H}, \mathrm{CH}_{\mathrm{ar}}\right) ; 7.25-7.29$ $\left(\mathrm{m}, 3 \mathrm{H}, \mathrm{CH}_{\mathrm{ar}}\right) ; 7.35-7.38\left(\mathrm{~m}, 2 \mathrm{H}, \mathrm{CH}_{\mathrm{ar}}\right) ; 7.40-7.44\left(\mathrm{~m}, 3 \mathrm{H}, \mathrm{CH}_{\mathrm{ar}}\right) ; 7.62\left(\mathrm{~s}, 1 \mathrm{H}, \mathrm{CH}_{\text {triazole }}\right) ; 7.83(\mathrm{~d}, 2 \mathrm{H}$, 
$\left.\mathrm{CH}_{\mathrm{ar}}\right) ; 8.09$ (s, 2H, $\left.\mathrm{CH}_{\mathrm{ar}}\right) .{ }^{13} \mathrm{C} \mathrm{NMR}\left(75 \mathrm{MHz}, \mathrm{CDCl}_{3}, \delta \mathrm{ppm}\right): 55.0\left(\mathrm{CH}_{3}\right) ; 103.4\left(\mathrm{CH}_{\mathrm{ar}}\right) ; 118.8\left(\mathrm{CH}_{\mathrm{ar}}\right)$; 121.0 $\left(\mathrm{CH}_{\mathrm{ar}}\right) ; 125.9\left(\mathrm{CH}_{\mathrm{ar}}\right) ; 126.7\left(2 \mathrm{CH}_{\mathrm{ar}}\right) ; 127.8\left(3 \times \mathrm{CH}_{\mathrm{ar}}\right) ; 128.1\left(\mathrm{CH}_{\text {triazole }}\right) ; 128.4\left(2 \times \mathrm{CH}_{\mathrm{ar}}\right) ; 129.3\left(\mathrm{C}_{\mathrm{ar}}\right)$; $129.6\left(\mathrm{CH}_{\mathrm{ar}}\right) ; 136.5\left(2 \mathrm{C}_{\mathrm{ar}}\right) ; 141.9\left(\mathrm{C}_{\text {triazole }}\right) ; 147.6\left(\mathrm{C}_{\mathrm{ar}}\right) ; 159.7\left(\mathrm{C}_{\text {carbonyl }}\right)$. HRMS (ESI) [M + H] ${ }^{+}$found $m / z=330.1198$. Calcd value for $\mathrm{C}_{20} \mathrm{H}_{15} \mathrm{~N}_{3} \mathrm{O}_{2}=330.1237$.

\subsubsection{Synthesis of Naphthalen-2-yl 1-(4-Methoxyphenyl)-1H-1,2,3-Triazole-4-Carboxylate (31)}

White solid. ${ }^{1} \mathrm{H}$ NMR (300 MHz, $\left.\mathrm{CDCl}_{3}, \delta \mathrm{ppm}\right): 3.82\left(\mathrm{~s}, 3 \mathrm{H}, \mathrm{CH}_{3}\right) ; 6.98-7.01\left(\mathrm{~d}, 2 \mathrm{H}, \mathrm{CH}_{\mathrm{ar}}\right)$; $7.18\left(\mathrm{~d}, 1 \mathrm{H}, \mathrm{CH}_{\mathrm{ar}}\right) ; 7.41-7.45\left(\mathrm{~m}, 1 \mathrm{H}, \mathrm{CH}_{\mathrm{ar}}\right) ; 7.62-7.67\left(\mathrm{~m}, 4 \mathrm{H}, \mathrm{CH}_{\mathrm{ar}}\right) ; 7.76-7.86\left(\mathrm{~m}, 3 \mathrm{H}, \mathrm{CH}_{\mathrm{ar}}\right) ; 8.54(\mathrm{~s}, 1 \mathrm{H}$, $\left.\mathrm{CH}_{\text {triazole }}\right) .{ }^{13} \mathrm{C}$ NMR $\left(75 \mathrm{MHz}, \mathrm{CDCl}_{3}, \delta \mathrm{ppm}\right): 55.7\left(\mathrm{CH}_{3}\right) ; 108.9\left(\mathrm{CH}_{\mathrm{ar}}\right) ; 115.1\left(2 * \mathrm{CH}_{\mathrm{ar}}\right) ; 118.8\left(\mathrm{CH}_{\mathrm{ar}}\right)$; 121.0 $\left(\mathrm{CH}_{\mathrm{ar}}\right) ; 122.6\left(\mathrm{CH}_{\mathrm{ar}}\right) ; 126.0\left(\mathrm{CH}_{\text {triazole }}\right) ; 126.6\left(2 \times \mathrm{CH}_{\mathrm{ar}}\right) ; 126.7\left(\mathrm{CH}_{\mathrm{ar}}\right) ; 127.9\left(\mathrm{CH}_{\mathrm{ar}}\right) ; 129.6\left(2 \times \mathrm{C}_{\mathrm{ar}}\right)$; $136.5\left(\mathrm{CH}_{\mathrm{ar}}\right) ; 142.1\left(\mathrm{C}_{\mathrm{ar}}\right) ; 147.6\left(\mathrm{C}_{\text {triazole }}\right) ; 158.6\left(\mathrm{C}_{\mathrm{ar}}\right) ; 159.7\left(\mathrm{C}_{\text {carbonyl }}\right) ; 164.1\left(\mathrm{C}_{\mathrm{ar}}\right)$. HRMS (ESI) [M + H] ${ }^{+}$ found $m / z=346.1206$. Calcd value for $\mathrm{C}_{20} \mathrm{H}_{15} \mathrm{~N}_{3} \mathrm{O}_{3}=346.1186$.

\subsection{Computational Methods}

All computational calculations were conducted using the Gaussian 09 program [58]. Optimized geometries were performed with B3LYP $[59,60]$, while the LANL2DZ basis set was used for the Cu atom [61] and the $6-31 \mathrm{G}(\mathrm{d}, \mathrm{p})$ basis set for the other atoms. Frequency calculations were performed to verify the stationary points to be real minima and each TS had only one single imaginary frequency at the same level. The solvent effects were performed with water as solvent using the polarizable continuum model (CPCM). All charge distributions were calculated by natural bond orbital (NBO) analysis [62]. All distances and energies are given in $\AA$ and kcal/mol, respectively.

The global electrophilicity $(\omega)$ and nucleophilicity $(N)$ indexes were measured at the same level, and are given by the following simple expressions: $\omega=\mu^{2} / 2 \eta$ and $N=E_{H}-E_{H}$ (TCE) $[63,64]$. The electronic chemical potential $(\mu)$ and chemical hardness $(\eta)$ were approached in terms of the one-electron energies of the frontier molecular orbitals HOMO and LUMO, $E_{H}$ and $E_{L}$, using the expressions $\mu=\left(E_{H}+E_{L}\right) / 2$ and $\eta=\left(E_{L}-E_{H}\right)$, respectively.

Both the electronic chemical potential $(\mu)$ and chemical hardness $(\eta)$ may be further approached in terms of the one-electron energies of the frontier molecular orbitals HOMO and LUMO, $E_{H}$ and $E_{L}$, using the expressions $\mu=\left(E_{H}+E_{L}\right) / 2$ and $\eta=\left(E_{L}-E_{H}\right)$, respectively.

Recently, Domingo et al. introduced a new local reactivity index for the Parr functions, namely, local electrophilic $\left(P_{k}^{+}\right)$, and nucleophilic $\left(P_{k}^{-}\right)$, obtained from the analysis of the Mulliken atomic spin density (ASD) of the corresponding reagents [65]. The ELF analysis was also carried out by means of Multiwfn software [66].

\section{Conclusions}

In summary, a copper(II) complex containing the heterocyclic 2-aminobenzothiazole (abt) as ligand was prepared and used as a precatalyst for the regioselective synthesis of the corresponding 1,4-disubstituted 1,2,3-triazole under CuAAC strict click chemistry regime. A variety of azides and alkynes were employed in the $\mathrm{CuAAC}$, affording the desired products, which were easily separated in excellent yields. In addition, the 32CA reaction between 5 and 4 was chosen as reaction model and the CuAAC mechanism was studied at the B3LYP/6-31G(d,p) (LANL2DZ for $\mathrm{Cu}$ ) computational level, choosing the abt as a ligand. The experimental findings are correctly explained by means of the local reactivity indexes obtained from the Parr functions, for regioselectivity synthesis of 1,4-triazoles. The reaction of Ac and $\mathbf{5}$ follows a two-step mechanism and an easy reaction in terms of energetics, which is in good agreement with the experimental observations. Importantly, the ionic nature of the starting Ac excludes any covalent interaction involving the copper(I) species throughout the reaction, as supported by the ELF topological analysis, indicating the $z w$-type pathway of the mechanism of $\mathrm{CuAAC}$ reactions, using abt as a ligand.

Supplementary Materials: The following are available online at http:/www.mdpi.com/2073-4344/10/7/776/s1. 
Author Contributions: Concept and work strategy were set up by L.B. and S.-E.S.; synthetic work was performed by L.B. and M.H.; computational calculations were done by L.B. and H.B.; data analysis and interpretation of experimental and theoretical results were carried out by L.B., H.A., M.J. and S.-E.S.; the writing of the manuscript was done by L.B., M.J. and S.-E.S. All authors have read and agreed to the published version of the manuscript.

Funding: This research received no external funding.

Acknowledgments: Financial support from the Spanish Ministerio de Ciencia e Innovación (MCINN) (Project CTQ 2016-75068P) is gratefully acknowledged.

Conflicts of Interest: The authors declare no conflict of interest.

\section{References}

1. Kolb, H.C.; Finn, M.G.; Sharpless, K.B. Click Chemistry: Diverse Chemical Function from a Few Good Reactions. Angew. Chem. Int. Ed. 2001, 40, 2004-2021. [CrossRef]

2. Lutz, J.-F. Nanotechnology for Life Science Research Group 1,3-dipolar cycloadditions of azides and alkynes: A universal ligation tool in polymer and materials science. Angew. Chem. Int. Ed. Engl. 2007, 46, 1018-1025. [CrossRef] [PubMed]

3. Agalave, S.G.; Maujan, S.R.; Pore, V.S. Click Chemistry: 1,2,3-Triazoles as Pharmacophores. Chem.-Asian J. 2011, 6, 2696-2718. [CrossRef]

4. Huisgen, R. 1,3-Dipolar Cycloadditions. Past and Future. Angew. Chem. Int. Ed. Engl. 1963, 2, 565-598. [CrossRef]

5. Huisgen, R. Kinetics and reaction mechanisms: Selected examples from the experience of forty years. Pure Appl. Chem. 1989, 61, 613-628. [CrossRef]

6. Meldal, M.; Tornøe, C.W. Cu-Catalyzed Azide-Alkyne Cycloaddition. Chem. Rev. 2008, 108, $2952-3015$. [CrossRef]

7. Rostovtsev, V.V.; Green, L.G.; Fokin, V.V.; Sharpless, K.B. A Stepwise Huisgen Cycloaddition Process: Copper(I)-Catalyzed Regioselective "Ligation" of Azides and Terminal Alkynes. Angew. Chem. Int. Ed. 2002, 41, 2596-2599. [CrossRef]

8. Nandivada, H.; Jiang, X.; Lahann, J. Click Chemistry: Versatility and Control in the Hands of Materials Scientists. Adv. Mater. 2007, 19, 2197-2208. [CrossRef]

9. Tron, G.C.; Pirali, T.; Billington, R.A.; Canonico, P.L.; Sorba, G.; Genazzani, A.A. Click chemistry reactions in medicinal chemistry: Applications of the 1,3-dipolar cycloaddition between azides and alkynes. Med. Res. Rev. 2008, 28, 278-308. [CrossRef]

10. Costa, M.S.; Boechat, N.; Rangel, É.A.; de C da Silva, F.; de Souza, A.M.T.; Rodrigues, C.R.; Castro, H.C.; Junior, I.N.; Lourenço, M.C.S.; Wardell, S.M.S.V.; et al. Synthesis, tuberculosis inhibitory activity, and SAR study of N-substituted-phenyl-1,2,3-triazole derivatives. Bioorg. Med. Chem. 2006, 14, 8644-8653. [CrossRef]

11. Wu, P.; Fokin, V.V. Catalytic azide-alkyne cycloaddition: Reactivity and applications. Aldrichimica Acta 2007, 40, 7-17. [CrossRef]

12. Rodionov, V.O.; Presolski, S.I.; Díaz Díaz, D.; Fokin, V.V.; Finn, M.G. Ligand-Accelerated Cu-Catalyzed Azide-Alkyne Cycloaddition: A Mechanistic Report. J. Am. Chem. Soc. 2007, 129, 12705-12712. [CrossRef]

13. Bahsis, L.; Ben El Ayouchia, H.; Anane, H.; Ramirez de Arellano, C.; Bentama, A.; El Hadrami, E.M.; Julve, M.; Domingo, L.R.; Stiriba, S.-E. Clicking Azides and Alkynes with Poly(pyrazolyl)borate-Copper(I) Catalysts: An Experimental and Computational Study. Catalysts 2019, 9, 687. [CrossRef]

14. Haldón, E.; Nicasio, M.C.; Pérez, P.J. Copper-catalysed azide-alkyne cycloadditions (CuAAC): An update. Org. Biomol. Chem. 2015, 13, 9528-9550. [CrossRef]

15. Singh, M.S.; Chowdhury, S.; Koley, S. Advances of azide-alkyne cycloaddition-click chemistry over the recent decade. Tetrahedron 2016, 72, 5257-5283. [CrossRef]

16. Yang, C.; Flynn, J.P.; Niu, J. Facile Synthesis of Sequence-Regulated Synthetic Polymers Using Orthogonal SuFEx and CuAAC Click Reactions. Angew. Chem. Int. Ed. 2018, 57, 16194-16199. [CrossRef] [PubMed]

17. Neumann, S.; Biewend, M.; Rana, S.; Binder, W.H. The CuAAC: Principles, Homogeneous and Heterogeneous Catalysts, and Novel Developments and Applications. Macromol. Rapid Commun. 2020, 41, 1900359. [CrossRef] [PubMed] 
18. Candelon, N.; Lastécouères, D.; Diallo, A.K.; Aranzaes, J.R.; Astruc, D.; Vincent, J.-M. A highly active and reusable copper(I)-tren catalyst for the "click"1,3-dipolar cycloaddition of azides and alkynes. Chem. Commun. 2008, 741-743. [CrossRef]

19. Bahsis, L.; Ben El Ayouchia, H.; Anane, H.; Triki, S.; Julve, M.; Stiriba, S.-E. Copper(II)-dipicolinate-mediated clickable azide-alkyne cycloaddition in water as solvent. J. Coord. Chem. 2018, 71, 633-643. [CrossRef]

20. Cano, I.; Nicasio, M.C.; Pérez, P.J. Copper(I) complexes as catalysts for the synthesis of N-sulfonyl-1,2,3 -triazoles from N-sulfonylazides and alkynes. Org. Biomol. Chem. 2010, 8, 536-538. [CrossRef]

21. Zhou, C.; Zhang, J.; Liu, P.; Xie, J.; Dai, B. 2-Pyrrolecarbaldiminato-Cu(II) complex catalyzed three-component 1,3-dipolar cycloaddition for 1,4-disubstituted 1,2,3-triazoles synthesis in water at room temperature. RSC Adv. 2014, 5, 6661-6665. [CrossRef]

22. Özçubukçu, S.; Ozkal, E.; Jimeno, C.; Pericàs, M.A. A Highly Active Catalyst for Huisgen 1,3-Dipolar Cycloadditions Based on the Tris(triazolyl)methanol-Cu(I) Structure. Org. Lett. 2009, 11, 4680-4683. [CrossRef] [PubMed]

23. Sharma, P.C.; Sinhmar, A.; Sharma, A.; Rajak, H.; Pathak, D.P. Medicinal significance of benzothiazole scaffold: An insight view. J. Enzyme Inhib. Med. Chem. 2013, 28, 240-266. [CrossRef]

24. Alang, G.; Kaur, R.; Kaur, G.; Singh, A.; Sïngla, P. Synthesis and antibacterial activity of some new benzothiazole derivatives. ACTA Pharm. Sci. 2010, 52, 213-218.

25. Catalano, A.; Carocci, A.; Defrenza, I.; Muraglia, M.; Carrieri, A.; Van Bambeke, F.; Rosato, A.; Corbo, F.; Franchini, C. 2-Aminobenzothiazole derivatives: Search for new antifungal agents. Eur. J. Med. Chem. 2013, 64, 357-364. [CrossRef]

26. Manjula, S.N.; Malleshappa Noolvi, N.; Vipan Parihar, K.; Manohara Reddy, S.A.; Ramani, V.; Gadad, A.K.; Singh, G.; Gopalan Kutty, N.; Mallikarjuna Rao, C. Synthesis and antitumor activity of optically active thiourea and their 2-aminobenzothiazole derivatives: A novel class of anticancer agents. Eur. J. Med. Chem. 2009, 44, 2923-2929. [CrossRef]

27. Kadirova, S.A.; Tursunova, M.R.; Ishankhodzhaeva, M.M.; Parpiev, N.A.; Karimov, Z.; Tozhiboev, A.; Tashkhodzhaev, B. Synthesis and structure of complexes of Co(II) acetate and Zn(II) chloride with 2-aminobenzothiazole. Russ. J. Gen. Chem. 2007, 77, 1807-1810. [CrossRef]

28. Dojer, B.; Pevec, A.; Breznik, K.; Jagličić, Z.; Gyergyek, S.; Kristl, M. Structural and thermal properties of new copper and nickel single-source precursors. J. Mol. Struct. 2019, 1194, 171-177. [CrossRef]

29. Shabana, A.A.; Butler, I.S.; Gilson, D.F.R.; Jean-Claude, B.J.; Mouhri, Z.S.; Mostafa, M.M.; Mostafa, S.I. Synthesis, characterization, anticancer activity and DNA interaction studies of new 2-aminobenzothiazole complexes; crystal structure and DFT calculations of [Ag(Habt)2]ClO4. Inorg. Chim. Acta 2014, 423, 242-255. [CrossRef]

30. BELMAR, J. New liquid crystals containing the benzothiazol unit: Amides and azo compounds. Liq. Cryst. 1999, 26, 389-396. [CrossRef]

31. İlkimen, H. A Review on Biological Properties and Mixed Ligand Metal Complexes Of 2-Aminobenzothiazoles. Pamukkale Univ. J. Eng. Sci. 2018, 24, 1360-1369. [CrossRef]

32. Reddy, K.R.; Rajgopal, K.; Kantam, M.L. Copper(II)-Promoted Regioselective Synthesis of 1,4-Disubstituted 1,2,3-Triazoles in Water. Synlett 2006, 2006, 957-959. [CrossRef]

33. Harmand, L.; Lescure, M.-H.; Candelon, N.; Duttine, M.; Lastécouères, D.; Vincent, J.-M. Huisgen click cycloadditions from a copper(II)-tren precatalyst without external sacrificial reductant. Tetrahedron Lett. 2012, 53, 1417-1420. [CrossRef]

34. Tale, R.H.; Gopula, V.B.; Toradmal, G.K. 'Click' ligand for 'click' chemistry: (1-(4-methoxybenzyl)-1-H-1,2,3triazol-4-yl)methanol (MBHTM) accelerated copper-catalyzed [3+2] azide-alkyne cycloaddition (CuAAC) at low catalyst loading. Tetrahedron Lett. 2015, 56, 5864-5869. [CrossRef]

35. Han, B.; Xiao, X.; Wang, L.; Ye, W.; Liu, X. Highly active binuclear Cu(II) catalyst bearing an unsymmetrical bipyridine-pyrazole-amine ligand for the azide-alkyne cycloaddition reaction. Chin. J. Catal. 2016, 37, 1446-1450. [CrossRef]

36. Bagherzadeh, M.; Bayrami, A.; Kia, R.; Amini, M.; Cook, L.J.K.; Raithby, P.R. Two new copper(II) complexes with chelating N,O-type bidentate ligands: Synthesis, characterization, crystal structure and catalytic activity in azide-alkyne cycloaddition reaction. Inorg. Chim. Acta 2017, 466, 398-404. [CrossRef] 
37. Amini, M.; Tekantappeh, S.B.; Eftekhari-Sis, B.; Derakhshandeh, P.G.; Hecke, K.V. Synthesis, characterization and catalytic properties of a copper-containing polyoxovanadate nanocluster in azide-alkyne cycloaddition. J. Coord. Chem. 2017, 70, 1564-1572. [CrossRef]

38. Kuang, G.-C.; Michaels, H.A.; Simmons, J.T.; Clark, R.J.; Zhu, L. Chelation-Assisted, Copper(II)-Acetate-Accelerated Azide-Alkyne Cycloaddition. J. Org. Chem. 2010, 75, 6540-6548. [CrossRef]

39. Brotherton, W.S.; Michaels, H.A.; Simmons, J.T.; Clark, R.J.; Dalal, N.S.; Zhu, L. Apparent Copper(II)-Accelerated Azide-Alkyne Cycloaddition. Org. Lett. 2009, 11, 4954-4957. [CrossRef]

40. Iacobucci, C.; Reale, S.; Gal, J.-F.; De Angelis, F. Dinuclear Copper Intermediates in Copper(I)-Catalyzed Azide-Alkyne Cycloaddition Directly Observed by Electrospray Ionization Mass Spectrometry. Angew. Chem. Int. Ed. 2015, 54, 3065-3068. [CrossRef]

41. Himo, F.; Lovell, T.; Hilgraf, R.; Rostovtsev, V.V.; Noodleman, L.; Sharpless, K.B.; Fokin, V.V. Copper(I)-Catalyzed Synthesis of Azoles. DFT Study Predicts Unprecedented Reactivity and Intermediates. J. Am. Chem. Soc. 2005, 127, 210-216. [CrossRef] [PubMed]

42. Nolte, C.; Mayer, P.; Straub, B.F. Isolation of a Copper(I) Triazolide: A “Click" Intermediate. Angew. Chem. Int. Ed. 2007, 46, 2101-2103. [CrossRef] [PubMed]

43. Albano, G.; Aronica, L.A. Acyl Sonogashira Cross-Coupling: State of the Art and Application to the Synthesis of Heterocyclic Compounds. Catalysts 2020, 10, 25. [CrossRef]

44. Berg, R.; Straub, B.F. Advancements in the mechanistic understanding of the copper-catalyzed azide-alkyne cycloaddition. Beilstein J. Org. Chem. 2013, 9, 2715-2750. [CrossRef]

45. Jin, L.; Tolentino, D.R.; Melaimi, M.; Bertrand, G. Isolation of bis(copper) key intermediates in Cu-catalyzed azide-alkyne "click reaction". Sci. Adv. 2015, 1, e1500304. [CrossRef]

46. Domingo, L.R. Molecular Electron Density Theory: A Modern View of Reactivity in Organic Chemistry. Molecules 2016, 21, 1319. [CrossRef]

47. Ríos-Gutiérrez, M.; Domingo, L.R. Unravelling the Mysteries of the [3+2] Cycloaddition Reactions. Eur. J. Org. Chem. 2019, 2019, 267-282. [CrossRef]

48. Domingo, L.R.; Aurell, M.J.; Pérez, P. A DFT analysis of the participation of zwitterionic TACs in polar [3+2] cycloaddition reactions. Tetrahedron 2014, 70, 4519-4525. [CrossRef]

49. Geerlings, P.; De Proft, F.; Langenaeker, W. Conceptual Density Functional Theory. Chem. Rev. 2003, 103, 1793-1874. [CrossRef]

50. Domingo, L.R.; Ríos-Gutiérrez, M.; Pérez, P. Applications of the Conceptual Density Functional Theory Indices to Organic Chemistry Reactivity. Molecules 2016, 21, 748. [CrossRef]

51. Domingo, L.R.; Aurell, M.J.; Pérez, P.; Contreras, R. Quantitative characterization of the global electrophilicity power of common diene/dienophile pairs in Diels-Alder reactions. Tetrahedron 2002, 58, 4417-4423. [CrossRef]

52. Jaramillo, P.; Domingo, L.R.; Chamorro, E.; Pérez, P. A further exploration of a nucleophilicity index based on the gas-phase ionization potentials. J. Mol. Struct. Theochem. 2008, 865, 68-72. [CrossRef]

53. Domingo, L.R. A new C-C bond formation model based on the quantum chemical topology of electron density. RSC Adv. 2014, 4, 32415-32428. [CrossRef]

54. Bahsis, L.; Ben El Ayouchia, H.; Anane, H.; Pascual-Álvarez, A.; Munno, G.D.; Julve, M.; Stiriba, S.-E. A reusable polymer-supported copper(I) catalyst for triazole click reaction on water: An experimental and computational study. Appl. Organomet. Chem. 2019, 33, e4669. [CrossRef]

55. Ben El Ayouchia, H.; Bahsis, L.; Anane, H.; Domingo, L.R.; Stiriba, S.-E. Understanding the mechanism and regioselectivity of the copper(I) catalyzed [3 + 2] cycloaddition reaction between azide and alkyne: A systematic DFT study. RSC Adv. 2018, 8, 7670-7678. [CrossRef]

56. Silvi, B. The synaptic order: A key concept to understand multicenter bonding. J. Mol. Struct. 2002, 614, 3-10. [CrossRef]

57. Domingo, L.R.; Ríos-Gutiérrez, M. A Molecular Electron Density Theory Study of the Reactivity of Azomethine Imine in [3+2] Cycloaddition Reactions. Molecules 2017, 22, 750. [CrossRef]

58. Frisch, M.J.; Trucks, G.W.; Schlegel, H.B.; Scuseria, G.E.; Robb, M.A.; Cheeseman, J.R.; Scalmani, G.; Barone, V.; Mennucci, B.; Petersson, G.A.; et al. Gaussian 09; Gaussian Inc.: Wallingford CT, USA, 2009.

59. Becke, A.D. Density-functional thermochemistry. III. The role of exact exchange. J. Chem. Phys. 1993, 98, 5648-5652. [CrossRef]

60. Lee, C.; Yang, W.; Parr, R.G. Development of the Colle-Salvetti correlation-energy formula into a functional of the electron density. Phys. Rev. B 1988, 37, 785-789. [CrossRef] 
61. Roy, L.E.; Hay, P.J.; Martin, R.L. Revised Basis Sets for the LANL Effective Core Potentials. J. Chem. Theory Comput. 2008, 4, 1029-1031. [CrossRef]

62. Yang, H.; Wong, M.W. Oxyanion hole stabilization by C-H...O interaction in a transition state-a three-point interaction model for Cinchona alkaloid-catalyzed asymmetric methanolysis of meso-cyclic anhydrides. J. Am. Chem. Soc. 2013, 135, 5808-5818. [CrossRef] [PubMed]

63. Parr, R.G.; Szentpály, L.v.; Liu, S. Electrophilicity Index. J. Am. Chem. Soc. 1999, 121, 1922-1924. [CrossRef]

64. Domingo, L.R.; Pérez, P. The nucleophilicity N index in organic chemistry. Org. Biomol. Chem. 2011, 9, 7168-7175. [CrossRef] [PubMed]

65. Domingo, L.R.; Pérez, P.; Sáez, J.A. Understanding the local reactivity in polar organic reactions through electrophilic and nucleophilic Parr functions. RSC Adv. 2013, 3, 1486-1494. [CrossRef]

66. Lu, T.; Chen, F. Multiwfn: A multifunctional wavefunction analyzer. J. Comput. Chem. 2012, 33, 580-592. [CrossRef]

(C) 2020 by the authors. Licensee MDPI, Basel, Switzerland. This article is an open access article distributed under the terms and conditions of the Creative Commons Attribution (CC BY) license (http://creativecommons.org/licenses/by/4.0/). 